Document downloaded from:

http://hdl.handle.net/10251/102485

This paper must be cited as:

Conesa-García, C.; Sánchez-Tudela, JL.; Pérez-Cutillas, P.; Martinez-Capel, F. (2018). Spatial variation of the vegetative roughness in Mediterranean torrential streams affected by check dams. Hydrological Sciences Journal. 63(1):114-135.

doi:10.1080/02626667.2017.1414384

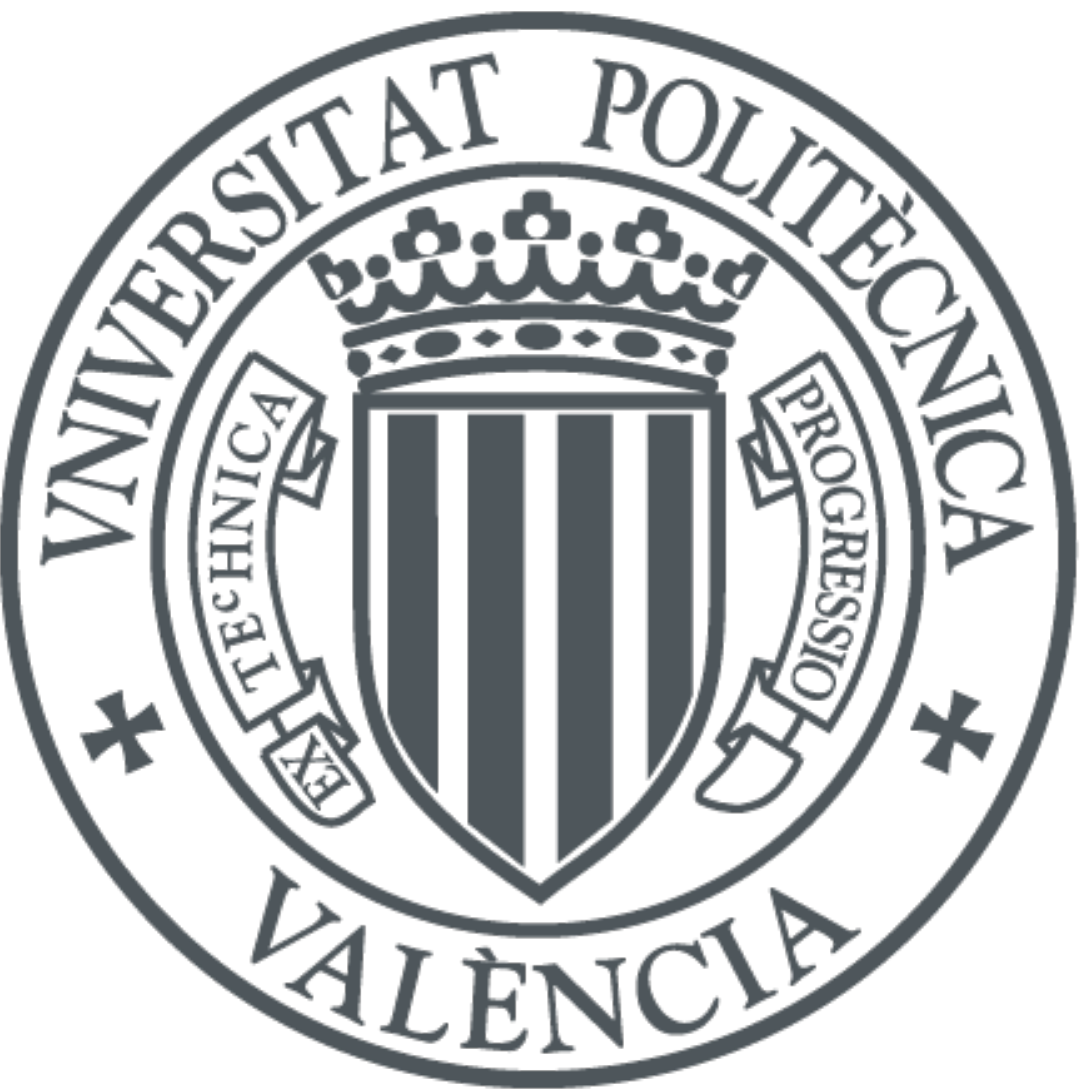

The final publication is available at

http://doi.org/10.1080/02626667.2017.1414384

Copyright Taylor \& Francis

Additional Information 


\title{
Spatial variation of the vegetative roughness in Mediterranean torrential streams affected by check dams
}

\author{
Carmelo Conesa-García a,*, José Luis Sánchez-Tudela, Pedro Pérez-Cutillas ${ }^{\text {b, }}$ \\ Francisco Martínez-Capel ${ }^{\mathrm{c}}$
}

\footnotetext{
a Department of Physical Geography, University of Murcia, Campus de La Merced, 30001 Murcia, Spain.

${ }^{\mathrm{b}}$ Centre of Soil Science and Applied Biology of the Segura River, Superior Council of Scientific Research, Espinardo, 30100 Murcia, Spain.

c Institut d'Investigació per a la Gestió Integrada de Zones Costaneres (IGIC), Universitat Politècnica de València (UPV), Gandia, Spain.

* Corresponding author.

E-mail address: cconesa@um.es (C. Conesa-García).
}

\begin{abstract}
This study focuses on the spatial variations in vegetative roughness associated with morphological channel adjustments due to the presence of check dams in Mediterranean torrential streams. Manning's n values were estimated using methods established by previous studies of submerged and non-submerged vegetation in laboratory flume experiments and field work. The results showed a linear decrease in shrub density and rate of variation of the roughness coefficient versus degree of submergence with increasing distance upstream from the check dam, while downstream, the filling of the check dam and the bed incision had the most influence. A regression analysis was applied by fitting the data to different models: relationships between Manning's $n$ and the flow velocity were found to be of the power type for shrubs in all upstream sections, while relationships of flow velocity versus hydraulic radius in the sections closest to check dams showed a good fit to secondorder polynomial equations.
\end{abstract}

Key words: hydraulic resistance; vegetative roughness; Mediterranean torrential streams; check dams; southeastern Iberian Peninsula

\section{INTRODUCTION}

The complex flow dynamics around vegetation has led to a large amount of research on vegetative roughness, mainly conducted in laboratory flumes and through field monitoring in open channels and floodplains (Hession and Curran 2013). Vegetative roughness in fluvial systems is a critical characteristic influencing water-surface elevations and flow velocity (Defra/EA 2003), sediment transport (Wu et al. 2006) and channel adjustments (Sandercock et al. 2007). Extensive research has been carried out to develop resistance laws for channels with rigid and flexible vegetation under different flow stages (e.g. Kouwen and FathiMoghadam 2000, Righetti and Armanini 2002, Okamoto and Nezu 2010, Aberle and Järvelä 2013). Most of the previous studies specifically focused on the flow resistance of either the submerged or the non-submerged vegetation in the main channels. Some researchers 
developed specific methods to estimate the roughness for flows over submerged and flexible vegetation (e.g. Kouwen and Unny 1973, Stephan and Gutknecht 2002, Kubrak et al. 2008). Others, such as Petryk and Bosmajian (1975), proposed models to estimate

Manning's $\mathrm{n}$ as a function of hydraulic radius and vegetation density for unsubmerged rigid vegetation.

Later, different experimental models were presented for evaluation of the unsubmerged and submerged vegetation resistance by hydraulic and vegetative parameters (e.g. Wu et al. 1999, Negm2008). More recently, Wynn-Thompson and Hall (2012) investigated the effect of clumping vegetation on flow resistance and developed an empirical equation for predicting the friction factor or drag coefficient in herbaceous emergent wetlands. Many theoretical and numerical investigations have also been performed, focusing mainly on evaluation of flow velocity and shear stress profiles and characterization of mean turbulence in vegetated channels (e.g.

Shimizu and Tsujimoto 1994, Fisher-Antze et al. 2001, Defina and Bixio 2005, Souliotis and Prinos 2010, Devi et al. 2017). However, the vegetative roughness in ephemeral streams has received relatively little attention.

Specifically, studies on hydraulic effects of riparian vegetation in gully headwaters are very scarce. Effects of manmade channel alterations on vegetation have not been widely studied up until now. Alterations to vegetation are considered to result in significant modifications to the resistance of vegetation during a flow, which then

greatly affects the channel hydraulics (Freeman et al. 2000, Dombroski et al. 2013). Changes in the composition, location and density of vegetation communities, associated with channel adjustments caused by these structures, contribute to important changes in resistance and flow hydraulics. Previous research has analysed the impact of check dams on riparian vegetation along torrential streams. Conesa-García and Pérez-Cutillas (2007) related the location of check dams to the adjacent vegetation cover in ephemeral gullies in southeastern Spain, using high-resolution QuickBird imagery. Bombino et al. (2014) investigated the effects on riparian species

diversity induced by check dams in torrent headwaters of southern Italy. Other work focused on the hydrological response of streams restored with check dams, where

vegetation plays a significant role (e.g. Norman et al. 2016). The installation of check dams breaks the longitudinal continuity of flash floods, influencing hydrological and sediment connectivity (Boix-Fayos et al. 2008), and thus causes drastic changes in vegetation and significant hydraulic effects. Vegetation acts to increase roughness and slow velocities, causing sediment to be deposited, thus developing a feedback mechanism whereby deposition can occur upstream above the height of the dam (Nichols et al. 2016). Downstream of check dams, scour holes also condition the development of vegetation and therefore its resistance to the flow. Such morphological adjustments have been studied by numerous authors in semi-arid environments (Puigdefábregas and García-Ruiz 1985, BoixFayos et al. 2007, 2008,

Castillo et al. 2007, Conesa-García et al. 2007, Conesa-García and García-Lorenzo 2009a, Conesa-García and García-Lorenzo 2010, Castillo et al. 2014, Galia and Skarpich 2016). This paper focuses on the effects of these morphological channel changes on spatial variations of vegetative roughness induced by the presence of check dams in Mediterranean semi-arid environments.

The primary objective of the present study was to analyse the influence of the check dams on the hydraulic resistance offered by the vegetation in corrected torrential channels. The patterns of vegetative roughness and the associated velocity distribution were determined from the biotechnical data described in Section 4.1 and the spatial variation in plant density (Section 4.2). Particular attention has been paid to changes in vegetative roughness 
associated with variations in hydraulic geometry, affecting the hydraulic radius and degree of submergence upstream and downstream of the check dams (Sections 4.3-4.5).

\section{STUDY AREA AND SELECTED CHANNEL REACHES}

The Torrecilla stream catchment $\left(15.5 \mathrm{~km}^{2}\right)$ is located in the southeast of Spain (Figure 1), within the internal area of the Betic ranges. The hydrological and rainfall regime here is dominated by a clear tendency towards aridity: mean annual rainfall below $300 \mathrm{~mm}$, potential annual evapotranspiration higher than $850 \mathrm{~mm}$, and prolonged periods of drought (Conesa-García et al., 2007). This contrasts with torrential rainfall of over $100 \mathrm{~mm}$ in just a few hours or even in a few 10-min periods, concentrated in late summer or autumn. The geological characteristics show complex structures worn down by ablation and metamorphic materials (slate, philites, schists, quarzites), locally mixed with sandstone and conglomerates rich in slates. The dense drainage network of this area produces a relief of rounded interfluves and channels that are generally not embedded (Figure 1). The high erodibility of the slatey schist materials and the steep mean slope of the catchment (32\%) lead to high scouring potential (Conesa-García and García-Lorenzo, 2009b).

The natural vegetation belongs to a transition zone between two bioclimatic stages: the upper thermo-Mediterranean and the warm meso-Mediterranean with a semi-arid ombroclimate (Alcaraz et al., 1999). Clear examples of this transition are found in the plant formations occupying ephemeral channels, known locally in Spain as ramblas, and gullies. In the lower reaches of the Torrecilla rambla there are small patches of the Almerian macroseries of ramblas characterized by Ziziphus lotus and Nerium oleander, with quite frequent and dense occurrences of Retama sphaerocarpa and Tamarix canariensis. In the middle and upper reaches there remain small riparian vestiges of Populus nigra with Rhamnus alaternus and N. oleander. All stretches show the presence of grasses (e.g Stipa tenacissima, Dittrichia viscosa), canes and reeds (e.g. Arundo donax and Phragmites australis), small shrubs (e.g. Ballota hirsuta, Genista umbellata), and scrubs (e.g. Artemisia barrelieri, Rosmarinus officinalis, Bassia scoparia). To combat the erosion in this area the Spanish government, through the Ministry of Agriculture, approved and implemented a forestry-hydraulic restoration project, which includes the repopulation of 1237 ha with pine (Pinus halepensis) and the construction of 33 check dams, the majority between 1972 and 1979, four between 1986 and 1988, and others after 1995. These check dams cause morphological adjustments both upstream (Up) and downstream (Dw), resulting in local changes in the spatial 
distribution of the riparian vegetation, as shown by the NDVI index values estimated for a 10-m buffer around the talweg (Conesa-García. and Pérez Cutillas, (2007) (Figure 1).

The studied reaches were selected according to the location of the check dams within the basin, their level of filling, the materials used in their construction, and the type of structure. In particular, three channel reaches affected by check dams were analyzed: a first reach with a gabion mesh dam located in the lower part of the Torrecilla rambla (T1), a second, with a masonry dam in the middle-lower part (T2), and a third, with a gabion structure, in the middle (T3) (Figures 1 and2).

The T1 check dam is a 2.7-m-high gabion construction, built in 1975. It is the closing dyke for the entire basin, but today it is no longer operational as a sediment trap since it has lost practically all of its storage capacity. This function has been taken upstream by the $6.7-\mathrm{m}$ high T2 dam, built in 1996 with hydraulic masonry. In both cases, a vertical bed incision took place next to the base of the dam, which continues the formation of a new, relatively modest channel excavated on top of the alluvial sediments themselves. The materials released in the incision process are evacuated from this channel and deposited downstream when the flow loses transport capacity. Previously, during the filling phase of the check dam, the floodwater loses much of its sediment load downstream and the bed is impacted by linear erosion, and the rocky substrate is exposed locally. Greater morphological adjustment is shown by the reach T3, located in the middle part of the stream. The check dam built in this reach has an age similar to that of the final stretch (T1) and, with a height of $3.9 \mathrm{~m}$, is almost blocked (it is only $0.5 \mathrm{~m}$ shy of being completely filled). Upstream, the sedimentary wedge appears well defined, and presents areas of temporary water logging in the vicinity of the transverse structure. Downstream, the scour hole reaches a certain longitudinal development, its depth being restricted by the outcropping of the metamorphic substrate.

\section{MATERIAL AND METHODS}

\subsection{Field Data and Measurements}

To estimate vegetative roughness, different reference reaches, which have a channel length of 90-250 m and a width of 12-25 m, were selected both upstream (Up) and downstream (Dw) of the three check dams T1, T2 and T3 (Fig. 2). Reach T1 is affected by a completely silted dam, while the check dams located in the T2 and T3 reaches are filled to about 20 and $75 \%$ of their capacity, respectively. Field data, including topographic and biotechnical 
measurements, were collected during the period from December 2013 to February 2014, along sedimentary wedges and scour holes located upstream and downstream of the dams, respectively.
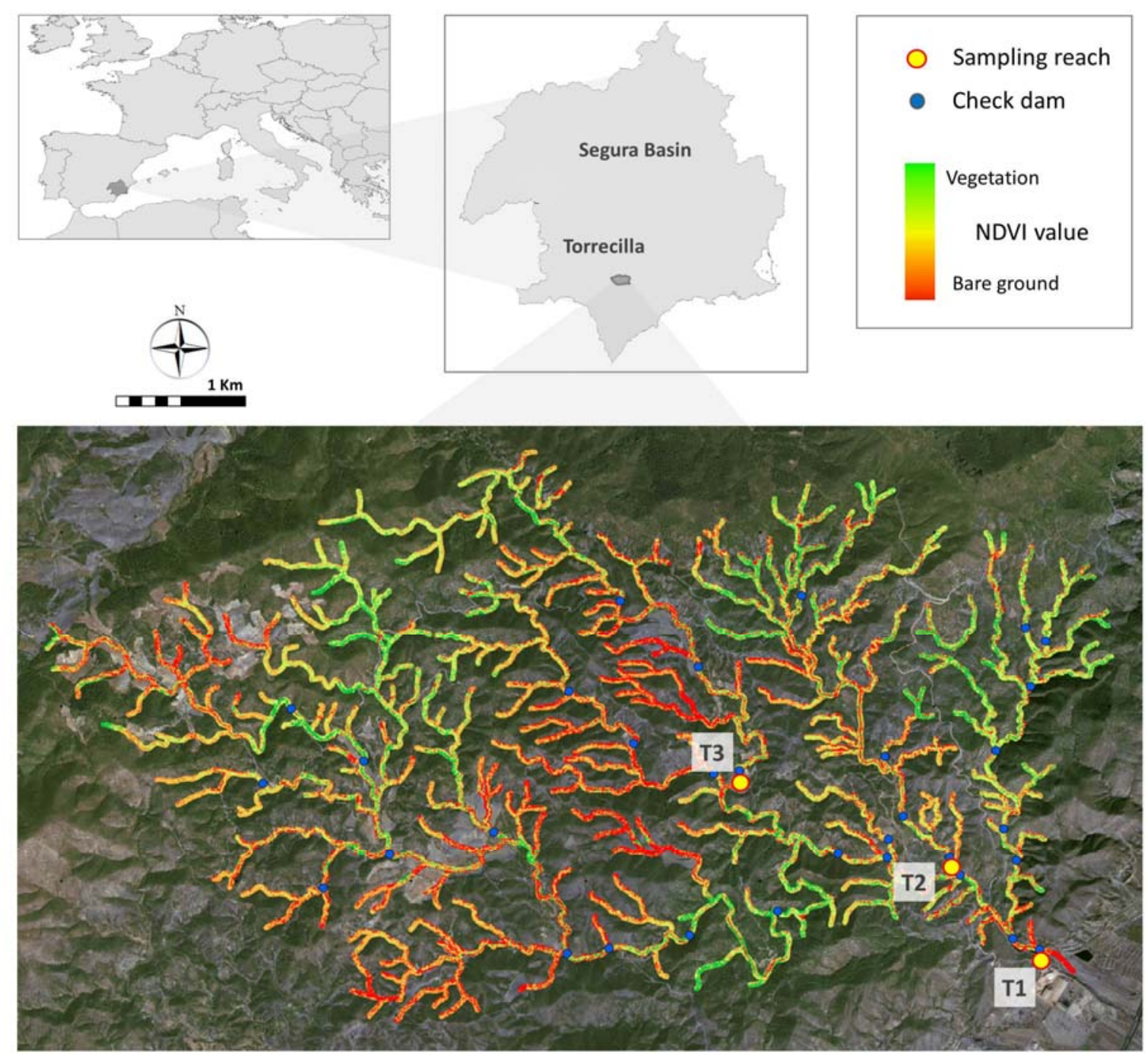

Figure 1. Location of the selected reaches in the Torrecilla catchment. Circles represent locations of check dams and sampling reaches.

For each reach (Up and Dw), biotechnical measurements were taken along three sections of $20 \mathrm{~m}$ length, starting at the beginning of each third of the sediment wedges and the scour holes generated by the dams: (1) close to the dam, avoiding the immediate area of turbulent flow; (2) located in the middle third of each studied reach; and (3) the farthest section from the check dam, within the last third. Thus, each reference reach consisted of three upstream monitoring sections (Up1, Up2 and Up3) and three downstream sections (Dw1, Dw2 and Dw3), whose enumeration represents their location relative to the dam. When the total length of a sedimentary wedge or scour hole allowed, a separation strip of $5 \mathrm{~m}$ was established between each pair of consecutive sections, to avoid possible mixing of the sampled 
individual plants at their boundaries (Fig. 3). As a general criterion, upstream and downstream of the dam, a flow length of $20 \mathrm{~m}$ projected over the vegetation was adopted within each section.
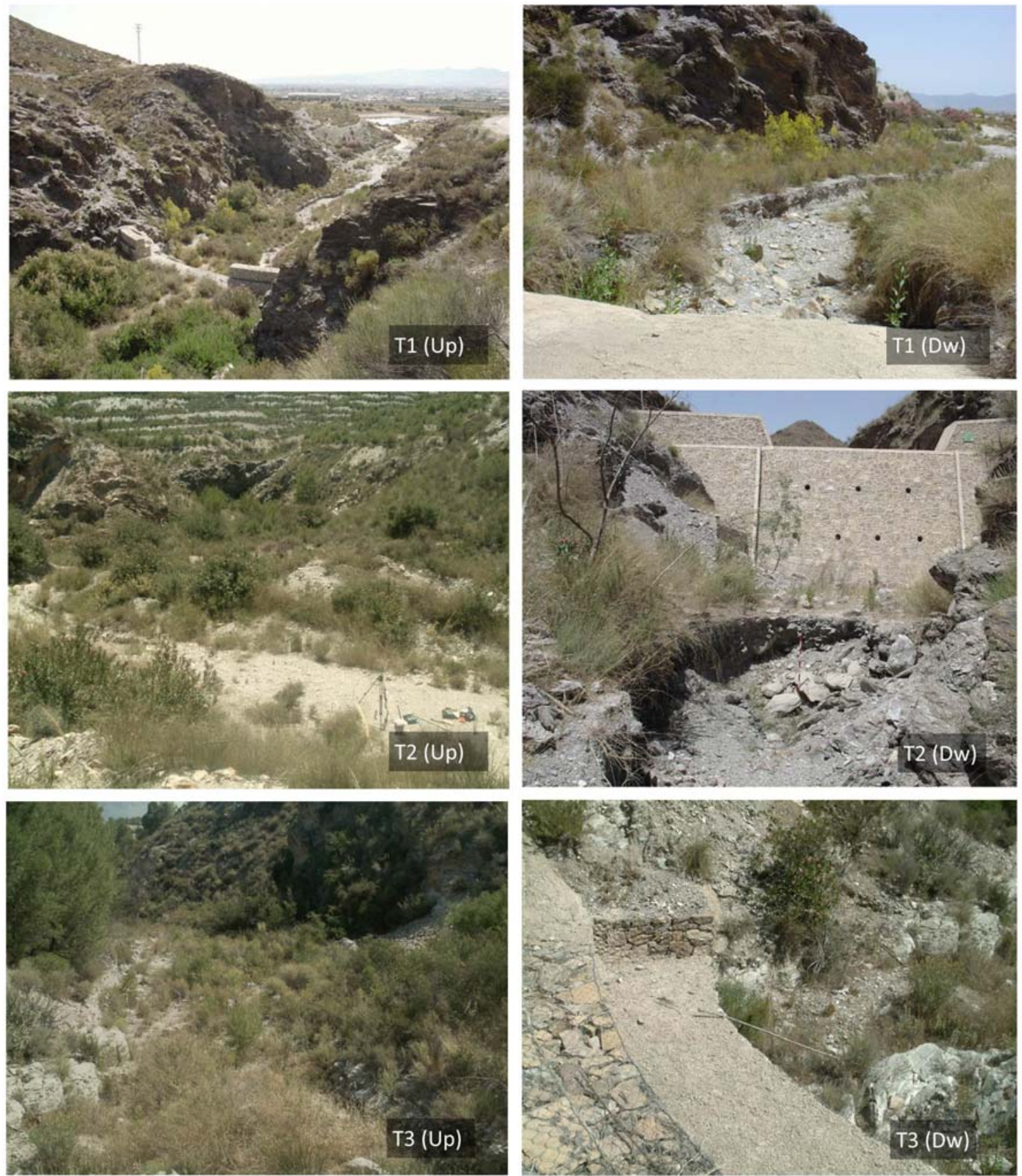

Figure 2. Riparian vegetation consisting mainly of oleanders (Nerium oleander), reeds (Phragmites australis), retama (Retama sphaerocarpa), and taray (Tamarix canariensis), which was especially dense upstream of the check dams studied (T1, T2 and T3). Stipa tenacissima dominates both the hillside and the old beds, currently hanging above the scour hole excavated downstream of these dams. 
Channel geometry and bed topography were obtained for each survey reach, using a Leica TCR 1103 total station and a Trimble 5700 dual-frequency GPS receiver. The GPS information was processed with Trimble Geomatics Office and Leica Survey Office software to obtain a common CAD-exportable file. This process gave centimetric precision in the digital elevation models thus generated and in the topographic profiles extracted from them. The study cross-sections were located in straight or non-sinuous channel reaches with little geometric variation, avoiding the proximity of gully junctions and turbulent sectors. Each channel cross-section selected for measurement was judged to be representative or typical after inspecting the entire reach.

\section{Flow direction}

Upstream

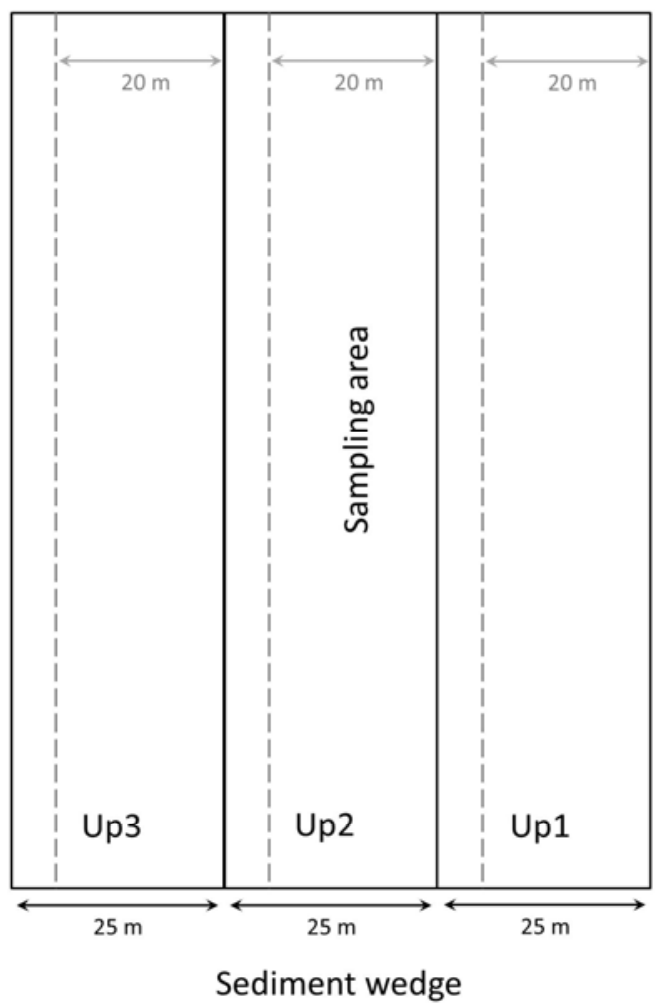

Donwstream
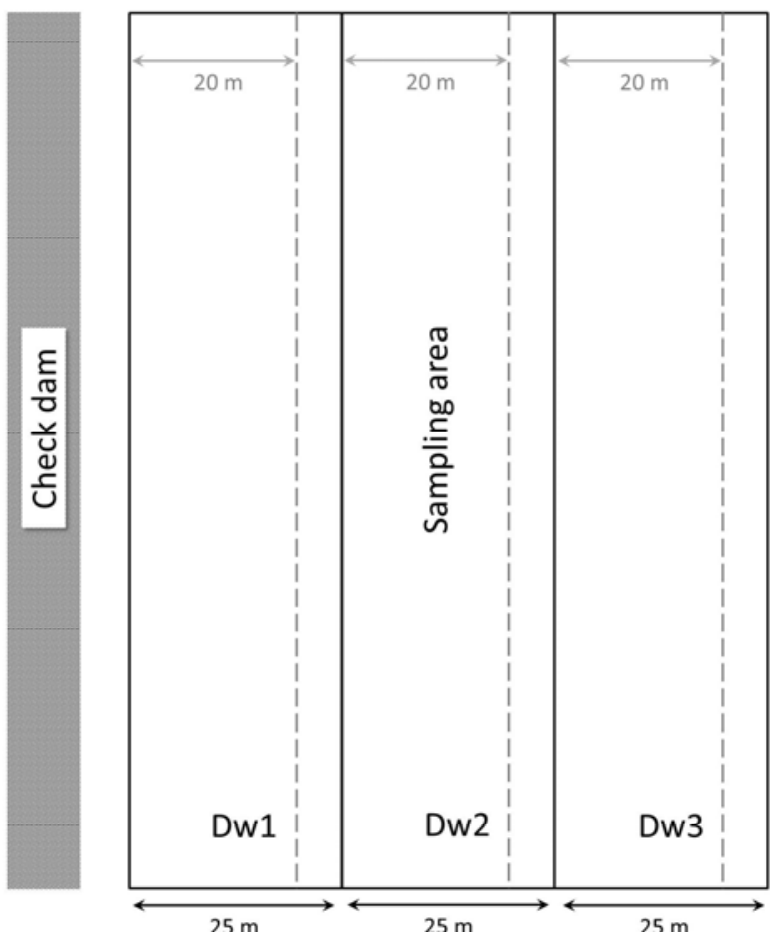

Scour hole

Figure 3. Explanatory sketch of the method used to delineate the sections where the transverse profiles of the channel and the biotechnical measurements of the vegetation were made. 


\subsection{Calculation of the Vegetative Roughness}

\subsubsection{Roughness of shrubs and scrubs}

The method proposed by Freeman et al. (2000) was adopted for the calculation of the vegetative roughness factor, for conditions of partially (Eq. 1) or totally (Eq. 2) submerged vegetation.

$$
\begin{gathered}
n_{v}=3.487 \cdot 10^{-5}\left(\frac{E_{S} \cdot A_{s}}{\rho \cdot A_{1}^{*} \cdot V_{*}^{2}}\right)^{0.15} \cdot\left(M \cdot A_{1}^{*}\right)^{0.166} \cdot\left(\frac{v}{V_{*} R h}\right)^{-0.622} \\
\cdot\left(\frac{R h^{2 / 3} S^{1 / 2}}{V_{*}}\right) \\
n_{v}=0.183\left(\frac{E_{S} \cdot A_{s}}{\rho \cdot A_{1}^{*} \cdot V_{*}^{2}}\right)^{0.183} \cdot\left(\frac{h_{s}}{h_{w}}\right)^{0.243} \cdot\left(M \cdot A_{1}^{*}\right)^{0.273} \cdot\left(\frac{v}{V_{*} R h}\right)^{0.115} \\
\cdot\left(\frac{R h^{2 / 3} S^{1 / 2}}{V_{*}}\right)
\end{gathered}
$$

where $E_{S}$ is the modulus of plant stiffness $\left(\mathrm{N} / \mathrm{m}^{2}\right) ; \rho$, the fluid density $\left(\mathrm{kg} / \mathrm{m}^{2}\right) ; A_{s}$, the total cross-sectional area of all of the stems of an individual plant measured at $\mathrm{h} / 4\left(\mathrm{~m}^{2}\right) ; A_{1}$, the frontal area of an individual plant blocking flow $\left(\mathrm{m}^{2}\right) ; A_{1}{ }^{*}$, the net submerged frontal area of a partially submerged plant $\left(\mathrm{m}^{2}\right) ; M$, the relative plant density (plants $/ \mathrm{m}^{2}$ ); $\mathrm{h}_{\mathrm{s}}$, the shrub height $(\mathrm{m}) ; \mathrm{h}_{\mathrm{w}}$, the water depth; $v$, the fluid dynamic viscosity $\left(\mathrm{m}^{2} / \mathrm{sec}\right) ; \mathrm{V}^{*}$, the shear velocity $(\mathrm{m} / \mathrm{s})$, and $S$, the bed slope (dimensionless). The modulus of stiffness $\left(E_{S}\right)$ was estimated according to the equation of Freeman et al. (2000) (Eq. 3), obtained from field and laboratory assays:

$$
E_{s}=7.648 \cdot 10^{6}\left(h_{s} / D_{s}\right)+2.174 \cdot 10^{4}\left(h_{s} / D_{s}\right)^{2}+1.809 \cdot 10^{3}\left(h_{s} / D_{s}\right)^{3}
$$

$A$ and $A_{1} *$ can be approximated by the equivalent rectangular area of blockage:

$$
\begin{aligned}
& A_{1}=\left(h_{s}-c b h\right) \cdot D_{c} \\
& A_{1}^{*}=\left(h_{w}-c b h\right) \cdot D_{c}
\end{aligned}
$$

while $A_{s}$ can be calculated as: 


$$
A_{s}=\pi\left(\frac{D_{s}}{2}\right)^{2} \cdot n_{s}
$$

where $\mathrm{D}_{\mathrm{s}}$ is the trunk diameter $(\mathrm{m})$; $\mathrm{D}_{\mathrm{c}}$, the crown diameter $(\mathrm{m})$ of an individual plant; cbh, the crown base height (m), and $n_{s}$, the number of stems.

\subsubsection{Roughness of the herbaceous vegetation}

The roughness of the herbaceous plants upstream and downstream of the check dams was estimated using the parameters established by Kouwen and Unny (1973), Kouwen and Li (1980), and Kouwen (1988) in laboratory flume experiments and field work. In particular, Kouwen's (1988) algorithm for grasses was applied to different submergence ratios $(\mathrm{y} / \mathrm{h})$ and hydraulic radii (Eq. 7).

$$
n_{v}=\left[\frac{1}{a+b \log \left(\frac{R h}{k}\right)}\right] \frac{R h^{1 / 6}}{\sqrt{8 g}}
$$

where $n_{v}$ is the Manning roughness coefficient for the vegetated channel area; $R h$, the hydraulic radius of the channel; $g$, the acceleration due to gravity; $k$, the deflected roughness height of the grass stems, defined by Eq. 11; and parameters " $a$ " and " $b$ " are a function of shear velocity $\left(\mathrm{V}^{*}\right)$, relative to critical shear velocity $\left(\mathrm{V}^{*}\right.$ rr), where the critical shear velocity depends on the density-stiffness property of the grass stems. $\mathrm{V}^{*}$ is defined by Eq. 8 from the bed shear stress $\left(\tau_{0}\right)$ and water density $(\rho)$, and $\mathrm{V}^{*}$, is the minimum value computed from equations 9 and 10.

$$
\begin{gathered}
V^{*}=\sqrt{\frac{\tau_{0}}{\rho}} \\
V^{*}{ }_{c r}=0.028+6.33 M E I^{2} \\
V^{*}{ }_{c r}=0.023 M E I^{0.106}
\end{gathered}
$$

Where MEI is an empirically defined vegetation parameter which represents the equivalent plastic flexural rigidity and density-stiffness. This refers to three significant stem properties: the stem density (M), the stem's modulus of elasticity (E), and the stem area's second 
moment of inertia (I). The deflected roughness height of the vegetation $(k)$ was calculated, using the Kouven and Li equation (Eq. 11), as a function of the amount of drag exerted by the flow and the parameter MEI:

$$
k=0.14 h_{h}\left[\frac{\left(\frac{M E I}{\tau_{0}}\right)^{1 / 4}}{h_{h}}\right]^{1.59}
$$

where $\tau$ is the bed shear stress, MEI the flexural rigidity, $h$ the un-deflected vegetation height $(\mathrm{m})$, and $\tau_{0}$ the bed shear stress $\left(\mathrm{N} / \mathrm{m}^{2}\right)$. MEI was calculated according to the equations provided by Darby (1999), from the specifications of Temple (1987) for growing and dormant grasses (Eqs. 12 and 13, respectively), as follows:

$$
\begin{aligned}
& M E I=319 h_{h}^{3.3} \\
& M E I=25.4 h_{h}^{2.26}
\end{aligned}
$$

Finally, the vegetative roughness was estimated for the overall channel $(n v c)$, which includes vegetated stretches and active bed forms (natural bare bed surface), using:

$$
n_{v c}=\left[n_{v} \cdot \%\left(A_{v}\right)\right] / 100
$$

where $n_{v}$ is the vegetative roughness corresponding to the vegetated part of the channel $\left(\mathrm{A}_{v}\right)$, and $\%\left(\mathrm{~A}_{\mathrm{v}}\right)$ is the percentage of vegetated area of the channel. The resistance data thus obtained were related to the flow velocity values estimated by the Manning equation (Eq. 15) for different hydraulic radii, and then analyzed using regression analysis, by fitting them to trend models.

$$
V=(1 / n) R h^{2 / 3} S^{1 / 2}
$$

where $\mathrm{V}$ is the mean velocity, $\mathrm{n}$ is Manning's roughness coefficient, $\mathrm{Rh}$ is the hydraulic radius, and $\mathrm{S}$ is the slope of the water sheet.

\section{RESULTS AND DISCUSSION}

The great spatial variability of the vegetation cover observed in the stretches of the studied stream results in values of global roughness that are also variable and bring about appreciable changes in the hydraulic regime. These changes, caused by the check dams, translate into 
variations in the velocity and height of the floodwater over short distances, usually associated with substantial morphological adjustments in the channel (Galia and Skarpich, 2016).

\subsection{Biotechnical data of the vegetation obtained for channel reaches with check dams}

The patterns of vegetative roughness and the associated velocity distribution were determined mainly by the different structural characteristics of each type of vegetation. Tables 1 and 2 show, by way of example, the values of the biotechnical parameters used in the calculation of the shrub and herbaceous roughness of reach T3, for flows with a hydraulic radius of $0.5 \mathrm{~m}$. This hydraulic radius corresponds to 10 -year flood peak discharges, generally responsible for the new bankfull channels developed downstream of these check dams (Conesa-García y García- Lorenzo, 2009c).

Table 1. Biotechnical parameters of the shrub and scrub vegetation upstream (Up) and downstream (Dw) of the check dam T3, for $R h=0.5 \mathrm{~m}$

\begin{tabular}{|c|c|c|c|c|c|c|c|c|c|c|}
\hline Sección & VT & $\mathrm{E}_{\mathrm{S}}$ & $\mathrm{A}_{\mathrm{S}}$ & $\mathrm{A}_{1}$ & $\mathrm{~A}_{1}{ }^{*}$ & $\mathrm{M}$ & Ds & Dc & $\mathrm{h}_{\mathrm{s}}$ & cbh \\
\hline \multirow{3}{*}{ Up1 } & $\mathrm{TC}$ & 226364247 & 8.04 & 3.3 & 1.52 & 0.02 & 0.02 & 5.5 & 2.2 & 0.04 \\
\hline & NO & 253710222 & 0.79 & 1.4 & 0.66 & 0.06 & 0.03 & 1.5 & 0.8 & 0.03 \\
\hline & $\mathrm{SC}$ & 1403348612 & 0.49 & 0.9 & 0.46 & 0.25 & 0.01 & 1 & 0.7 & 0.012 \\
\hline \multirow{3}{*}{ Up2 } & $\mathrm{TC}$ & 573890664 & 7.07 & 2.9 & 1.36 & 0.01 & 0.05 & 3.1 & 2.3 & 0.03 \\
\hline & NO & 532698496 & 5.31 & 2.1 & 0.92 & 0.05 & 0.05 & 3.4 & 2.2 & 0.06 \\
\hline & $\mathrm{SC}$ & 686559399 & 0.43 & 0.8 & 0.41 & 0.32 & 0.01 & 0.9 & 0.7 & 0.013 \\
\hline \multirow{3}{*}{ Up3 } & $\mathrm{TC}$ & 573890664 & 7.07 & 2.9 & 1.36 & 0.01 & 0.05 & 3 & 2.3 & 0.03 \\
\hline & $\mathrm{NO}$ & 307156025 & 7.74 & 3.2 & 1.34 & 0.01 & 0.08 & 4.1 & 2.3 & 0.075 \\
\hline & $\mathrm{SC}$ & 495598309 & 0.34 & 0.8 & 0.4 & 0.29 & 0.02 & 0.9 & 0.8 & 0.015 \\
\hline \multirow{2}{*}{ Dw1 } & $\mathrm{TC}$ & 573890664 & 7.07 & 2.9 & 1.36 & 0.01 & 0.05 & 3.1 & 2.3 & 0.03 \\
\hline & $\mathrm{SC}$ & 1269921507 & 0.09 & 0.5 & 0.26 & 0.22 & 0.01 & 0.6 & 0.6 & 0.012 \\
\hline \multirow{2}{*}{ Dw2 } & NO & 532698496 & 5.3 & 2.1 & 0.92 & 0.05 & 0.05 & 3.4 & 2.2 & 0.06 \\
\hline & $\mathrm{SC}$ & 1262373000 & 0.34 & 0.9 & 0.42 & 0.21 & 0.01 & 0.9 & 0.7 & 0.01 \\
\hline Dw3 & $\mathrm{SC}$ & 715255404 & 0.28 & 0.7 & 0.33 & 0.26 & 0.014 & 0.7 & 0.7 & 0.014 \\
\hline
\end{tabular}

$\mathrm{VT}=$ vegetation type $\mathrm{TC}=$ Tamarix canariensis $\mathrm{NO}=$ Nerium oleander $; \mathrm{SC}=\mathrm{Scrubs}$;

$\mathrm{E}_{\mathrm{S}}=$ modulus of plant stiffness $\left(\mathrm{N} / \mathrm{m}^{2}\right) ; \mathrm{N}=$ number of plants along a channel reach having length $\mathrm{L}(\mathrm{m}) ; A_{S}=$ total cross-sectional area of all of the stems of an individual plant measured at $\mathrm{h} / 4\left(\mathrm{~m}^{2}\right) ; A_{l}=$ frontal area of an individual plant blocking flow $\left(\mathrm{m}^{2}\right) ; A_{1}^{*}=$ net submerged frontal area of a partially submerged plant $\left(\mathrm{m}^{2}\right)$; $M=$ relative plant density $\left(\right.$ plants $\left./ \mathrm{m}^{2}\right) ; \mathrm{Ds}=$ trunk diameter $(\mathrm{m})$; Dc $=$ crown diameter $(\mathrm{m})$ of an individual plant; $h_{\mathrm{s}}=$ shrub height; $\mathrm{cbh}=$ crown base height $(\mathrm{m})$. 
From Table 1, it can be inferred that the stiffness modulus of the woody plants $\left(E_{s}\right)$ exerted its greatest influence on the vegetative roughness in the section upstream of the dam (Up1), with an Es value of $14.03 \cdot 10^{8} \mathrm{~N} / \mathrm{m}^{2}$, and decreased with the distance from the said structure, reaching $3.07 \cdot 10^{8} \mathrm{~N} / \mathrm{m}^{2}$ for Up3. Downstream, the relative influence of this module was also greater in the sections closest to the dam, where the values of $E_{s}$ were maximal, around $12.65 \cdot 10^{8} \mathrm{~N} / \mathrm{m}^{2}$. The number of individuals $(\mathrm{N})$ was increased in the sections furthest from the dam in the Dw sub-reach, while the mean cross-sectional area of the scrub measured at $\mathrm{h} / 4$ (As) decreased from Up1 to Up3 and from Dw3 to Dw1.

In all sections, Tamarix canariensis had similar values of stiffness $\left(2.25 \cdot 10^{8} \mathrm{~N} / \mathrm{m}^{2}<\mathrm{E}_{\mathrm{s}}<\right.$ $\left.5.75 \cdot 10^{8} \mathrm{~N} / \mathrm{m}^{2}\right)$, As $\left(7-8 \mathrm{~m}^{2}\right)$, and $\mathrm{A}_{1} *\left(1.36\right.$ to $\left.1.52 \mathrm{~m}^{2}\right)$. In contrast, in the case of Nerium oleander and the scrubs, a wider range of values was observed for these parameters, depending on the distance to the check dam (Table 1). It is noteworthy also that the shrub species had a greater presence in the Up sections.

Regarding the biotechnical parameters of the herbaceous vegetation, the height of deflected roughness of this type of plant (factor $k$ ) decreased slightly from Up1 to Up2 and from Dw2 to Dw1, the empirical parameter of stiffness (MEI) varied in the same way, and the relative density of plants (M) was much lower throughout Dw and in Up3 $\left(0.1\right.$ individuals $\left./ \mathrm{m}^{2}\right)$ than in Up1 (0.33 individuals $\left./ \mathrm{m}^{2}\right)$ (Table 2).

Table 2. Biotechnical parameters of the herbaceous vegetation and hydraulic variables upstream (Up) and downstream (Dw) of the T3 check dam, for $\mathrm{Rh}=0.5 \mathrm{~m}$.

\begin{tabular}{cccccccccccc}
\hline Section & $\tau_{0}$ & $\mathrm{~V}^{*}$ & $\mathrm{~V}^{*}{ }_{\mathrm{c}}$ & $\mathrm{V}^{*} / \mathrm{V}^{*}{ }_{\mathrm{c}}$ & $\mathrm{N}$ & $\mathrm{M}$ & $K$ & $\mathrm{~h}_{\mathrm{h}}$ & $\mathrm{a}$ & $\mathrm{b}$ & MEI \\
\hline Up1 & 117.7 & 0.34 & 0.32 & 1.08 & 49 & 0.33 & 0.074 & 0.92 & 0.2 & 2.7 & 21.27 \\
Up2 & 132.4 & 0.36 & 0.31 & 1.18 & 30 & 0.16 & 0.068 & 0.8 & 0.2 & 2.7 & 15.34 \\
Up3 & 147.1 & 0.38 & 0.34 & 1.13 & 18 & 0.10 & 0.070 & 1.21 & 0.2 & 2.7 & 39.04 \\
Dw1 & 137.3 & 0.37 & 0.27 & 1.36 & 15 & 0.10 & 0.057 & 0.49 & 0.2 & 2.7 & 5.07 \\
Dw2 & 152.0 & 0.39 & 0.31 & 1.25 & 13 & 0.09 & 0.065 & 0.84 & 0.2 & 2.7 & 17.13 \\
Dw3 & 156.9 & 0.40 & 0.31 & 1.26 & 26 & 0.12 & 0.065 & 0.87 & 0.2 & 2.7 & 18.74 \\
\hline
\end{tabular}

$\tau_{0}=$ bed shear stress $\left(\mathrm{N} / \mathrm{m}^{2}\right) ; \mathrm{V}^{*}=$ shear velocity $(\mathrm{m} / \mathrm{s}) ; \mathrm{V}^{*}{ }_{\mathrm{cr}}=$ critical shear velocity; $\mathrm{V}^{*} / \mathrm{V}^{*}{ }_{\mathrm{cr}}=$ ratio between shear velocity and critical shear velocity; $\mathrm{N}=$ number of plants along a channel reach $(\mathrm{m}) ; M$, the relative plant density (plants $\left./ \mathrm{m}^{2}\right) ; \mathrm{K}=$ Deflected roughness height of herbaceous vegetation, defined by Eq. $11 ; \mathrm{h}_{\mathrm{h}}=$ local height of the strips; $a$ and $b=$ relative roughness parameters depending on the ratio between the shear velocity and its critical value; $\mathrm{MEI}=$ empirical vegetation stiffness parameter. 


\subsection{Spatial variation of the vegetation density in channel reaches controlled by dams}

The check dams have had an important effect on the spatial distribution and density of the bed vegetation (M) (Figure 5). Upstream (Up), the density of vegetation tended to decrease progressively according to the distance to the dam, while downstream (Dw) the reverse happened. In addition, except for T2, whose downstream end barely showed any structural influence, the vegetation cover in the upstream section furthest from the dyke (Up3) was denser than in the most distant section downstream (Dw3). This behavior was particularly accentuated in the lower reach of the channel, especially in the closing dam (T1). In the middle-lower and middle stretches the differences between sections within each sub-reach were reduced, although the contrast was maintained from one sub-reach to another.

The spatial variation of plant density along the bed was closely related to the morphological adjustments caused by the dams (Boix-Fayos et al., 2007; Bombino et al., 2010, 2014). In all cases, the upstream section closest to the dam (Up1) had a higher vegetation density (M $>0.3$ individuals $/ \mathrm{m}^{2}$ ). This section is located in the area that, since the construction of the dam, has suffered the greatest accumulation of water and sediments at times of flash floods. However, the degree of plant colonization and the nature of the dominant vegetation in these sections depend on the type of construction and the state of the dam. Overfilled check dams (e.g. T1) induce a significant reduction of the bed slope upstream (Up) and of the flow velocity, compared to what existed before construction (Conesa-García et al., 2007). In dams with 50\% refill (e.g. T3), the greatest bed slope reduction and average shear stress are still produced immediately upstream of the check dam, in Up1. In this case, almost all the sedimentary wedge is covered by shallow waters and waterlogged sectors during the flood events, which ensures the wetting of the bed for several days or weeks and favors the growth of herbaceous plants, sedges, and reeds $\left(\mathrm{M}=0.33\right.$ individuals $\left./ \mathrm{m}^{2}\right)$. Check dams with refill equal to or less than $20 \%$ (e.g. T2) represent recently built dams, where geomorphological effects are still incipient. Upstream from these check dams the channel morphology has hardly changed; there is also a reduced flat base formed on a thin layer of pebbles and gravels. The vegetation cover has undergone fewer changes than in the previously described cases, and different types of vegetation had similar occupation densities, although with a slight predominance of scrubs $\left(\mathrm{M}=0.25\right.$ individuals $\left./ \mathrm{m}^{2}\right)$. The vegetation cover became somewhat less dense towards section Up2 and decreased notably in Up3 (Figure 4). 

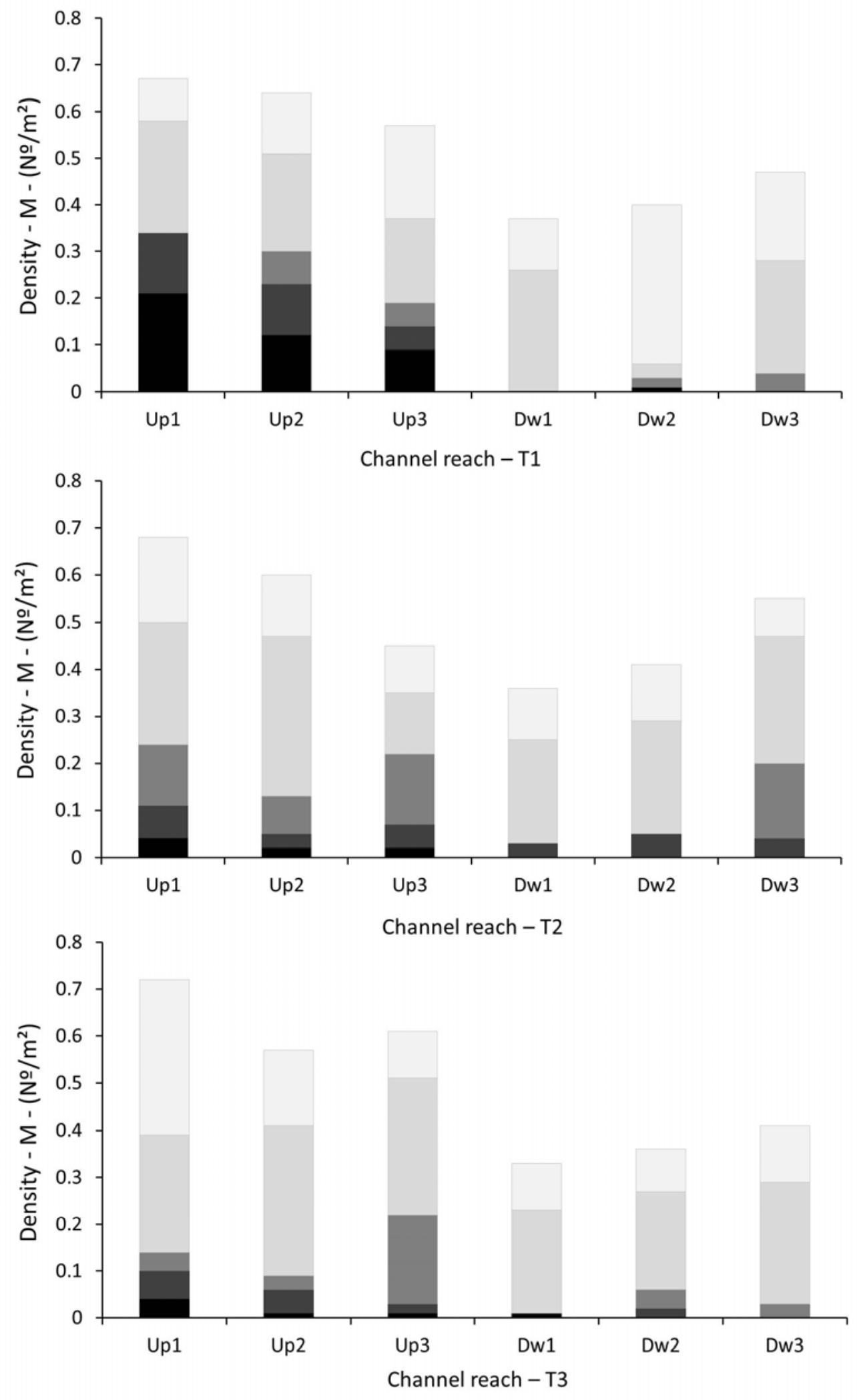

-Tamarix $\square$ N. oleander $\square$ Other shrubs Scrubs Herbaceous

Figure 4. Density of the vegetation obtained for different formations and individuals in the upstream (Up) and downstream (Dw) sub-reaches of the studied check dams. 
The vegetation was less dense in the stretches downstream of the check dams (Dw), a consequence of greater geomorphological activity (intense excavation and superficial washing of the bed). The scouring bed-forms produced here reach their maximum development before the check dams are refilled, frequently when the fill-up constitutes twothirds of the structure's initial capacity (Conesa-García and García-Lorenzo, 2009b). Later, sediment provision recommences, draping the bedrock and boulders previously uncovered by erosion, while bed elevation remains relatively stable after the local erosion at the base of the check dam develops (maximum stability phase). These morphological adjustments are in accordance with those observed downstream of check dams in arid gully headwaters (Nyssen et al., 2004) and semi-arid watersheds (Polyakov et al., 2014; Norman et al., 2016). When the check dam is empty or there is little sediment, as at T2, the alluvial substrate, due to its permeable nature, allows sub-superficial flow under the structure. In this way a hole develops immediately downstream of the check dam, usually being smaller than those caused by the hydraulic jump. As a result of this, Dw1 was the section with the lowest vegetation density of all those analyzed. In the downstream direction, the presence of vegetation was more evident in the sections furthest from the dam (Dw2 and Dw3), where the effects of the erosion wedge fade.

\subsection{Variation of the vegetative roughness with the degree of submergence}

The contributions of different vegetative roughness types to the total flow resistance depend strongly on the type and combination of the vegetation and the variability exhibited in relation to submergence levels (Wu et al., 1999; Järvelä, 2002). Such variability is even more marked during flash floods that affect ephemeral channels corrected by check dams. Under these conditions, the roughness of the vegetation can register very frequent and abrupt changes, associated with rapid variations of the degree of submersion, which is defined as the ratio of the flow depth (y) to the height of the vegetation (h).

Figure 5 shows the variations of $n_{v}$ with respect to the ratio $y / h$ estimated for two types of characteristic shrubs in the Up sections of the dams studied: T. canariensis and N. oleander. From Figure 5, it is easy to see that the $n_{v}$ distributions have similar positive trends. In all cases, $n_{v}$ increases linearly as $y / h$ rises. This result is in accordance with the previous hypothesis of Temple et al. (1987), who attributed the increase in the unsubmerged vegetative roughness coefficient to the greater bulk of overbank vegetation and branches/leaves encountered with the increasing depth. In particular, the frontal area of these 
shrubs blocking the flow $\left(\mathrm{A}_{1}\right)$ and the net submerged frontal area when they are partially submerged $\left(\mathrm{A}_{1}{ }^{*}\right)$ increased with the height of the flow in all the flash floods of $R h \leq 1.5 \mathrm{~m}$. Also, Fathi-Moghadam and Drikvandi (2012) found a linear increase in the n-value with increasing density and ratio of submergence for taray, in both cases due to increasing roughness elements.

Tamarix - Upstream
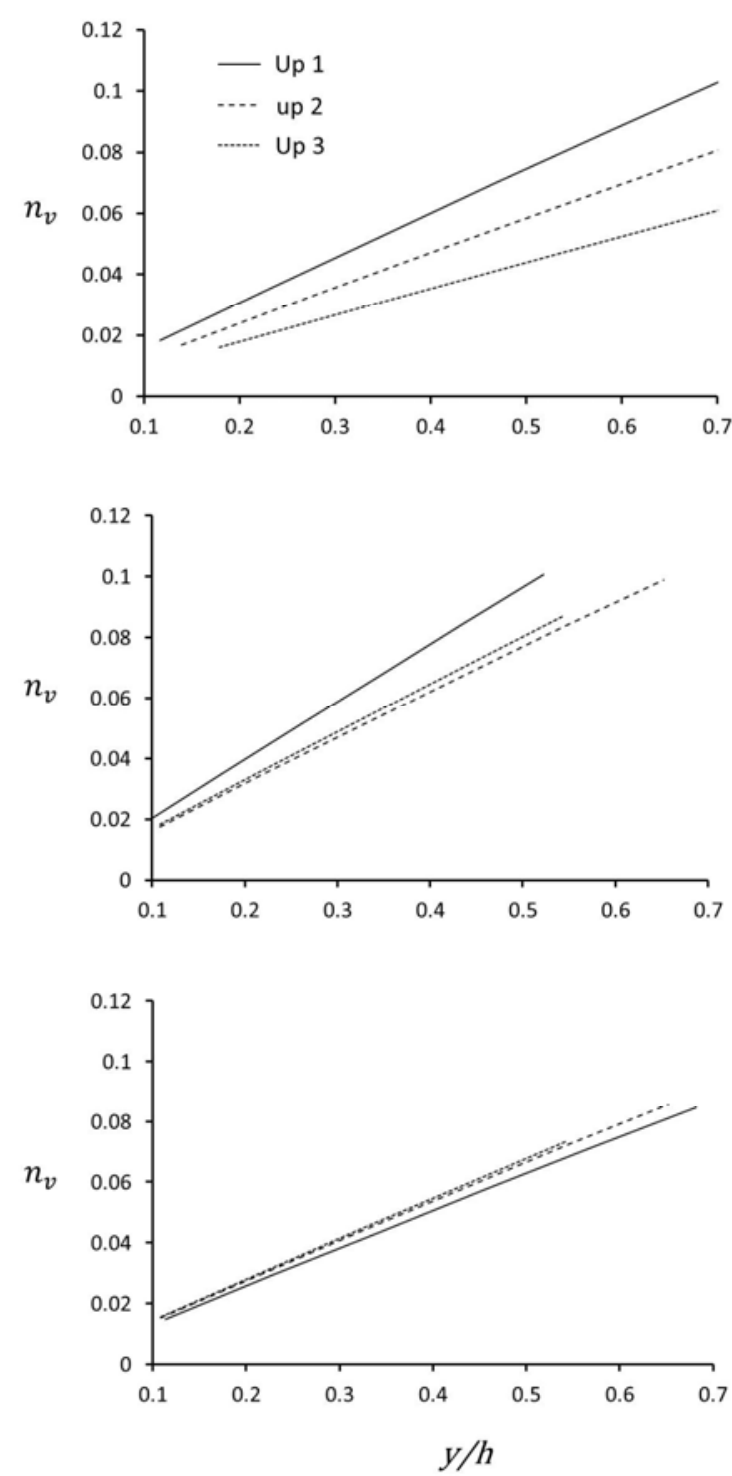

N. oleander - Upstream
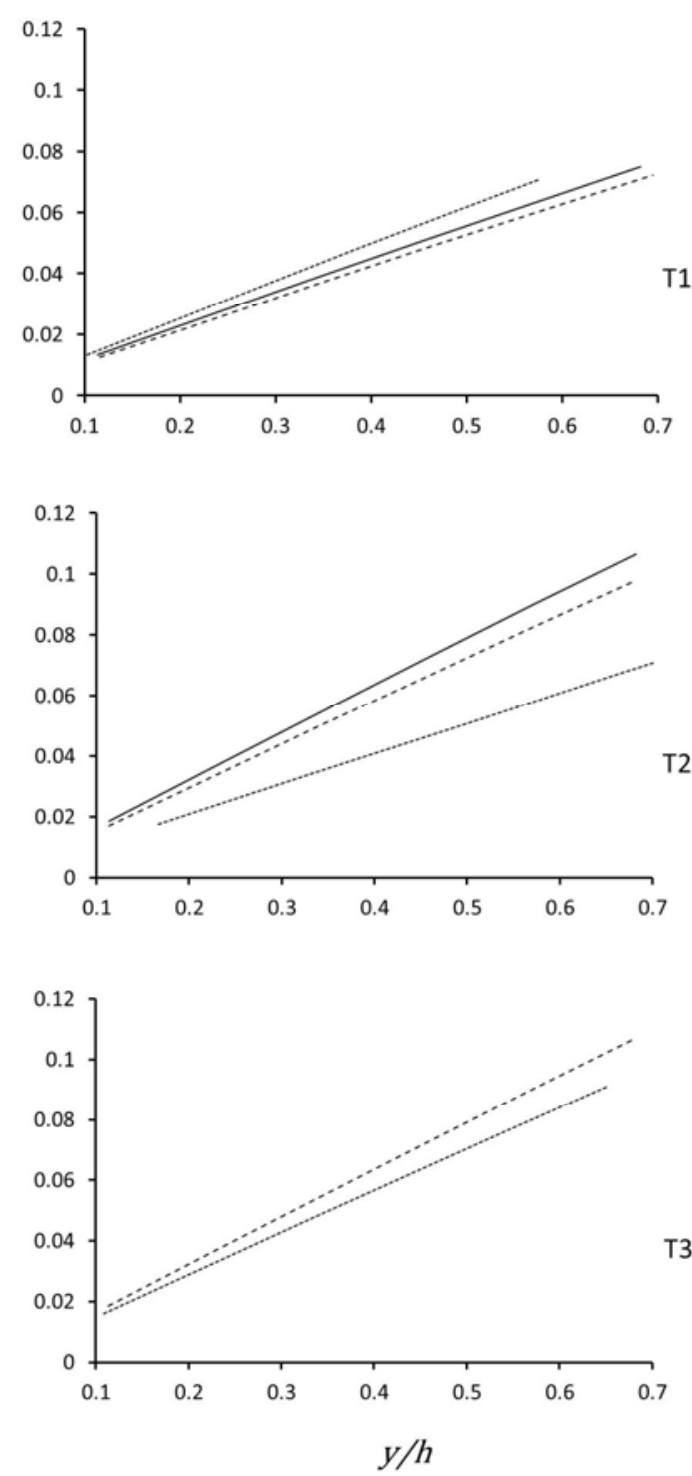

Figure 5. Relationships between Manning's nv and the degree of submergence, $\mathrm{y} / \mathrm{h}$, for shrubs (Tamarix canariensis and Nerium oleander) upstream from check dams T1, T2 and T3. 
However, the rate of variation of $n_{v}$ versus the submergence ratio differed depending on the species type and the development of the species. Taking as an example the section immediately upstream of $\mathrm{T} 1(\mathrm{Up} 1)$, as $y / h$ rises from 0.1 to 0.7 , there was an increase in $\mathrm{A}_{1}$ * of $1.37 \mathrm{~m}^{2}$ and an increase in $n_{v}$ of 0.077 for $T$. canariensis, while for $N$. oleander such increases were somewhat smaller $\left(\Delta \mathrm{A}_{1} *=0.86 \mathrm{~m}^{2}\right.$ and $\left.\Delta n_{v}=0.062\right)$. With the distance from this dam, also the density of taray decreased- which, together with the lower values of $E_{s}$, $\mathrm{A}_{\mathrm{s}}$, and $\mathrm{A}_{1} *$ of this species in sections Up2 and Up3, means that the rate of variation of $n_{v}$ with respect to $y / h$ decreased in an upstream direction. This was not the case with $N$. oleander, whose biotechnical parameters did not seem to be affected by the proximity to the check dam. Although incipient, the influence of the T2 dam was noticeable in the behavior of both types of shrub in the Up sections, especially for $T$. canariensis, whose $n_{v}$ value exhibited practically the same range of increase as in $\mathrm{T} 1, \mathrm{y} / \mathrm{h}$ passing from 0.1 to 0.5 . In $\mathrm{T} 3$ the tarays had a lesser development and maturity, in addition to a very low density $(\mathrm{M}<$ $10 \%$ ); therefore, the effect of the submergence ratio was less significant. It is of note that the channel section affected by this check dam, still in the process of filling, was undergoing intense geomorphological activity.

The roughness of the scrub and herbaceous plants showed different patterns. The scrub, less flexible in low-water conditions, offered greater initial resistance to the flow, associated with moderate roughness values that tended to increase to the submersion level $(y / h \geq 1)$ (Freeman et al., 2000), from which point this tendency changed with the height of the water. In contrast, in the case of herbaceous plants, the decrease in roughness in relation to the ratio $y / h$ was continuous. The Manning's $n_{v}$ value calculated for herbaceous plants in the present study is in agreement with the results of El Hakim and Salama (1992), Reza Mahbub and Suzuki (1998), and Abood et al. (2006). The deflected height and the Manning's $n_{v}$ value decreased with increasing flow depth and velocity. Following total submersion, the coefficient $n_{v}$ decreased at a smoother rate relative to the ratio $y / h$, no longer depending on it after $y / h$ reached a value of 2 . Both patterns include specific modalities depending on the channel stretch affected by the dam.

Figure 6 shows the relationships between Manning's $n_{v}$ and the degree of submergence, $y / h$, for scrubs upstream (Up) and downstream (Dw) of check dams T1, T2, and T3. The pattern, represented by the Up sections of the $\mathrm{T} 1$ and $\mathrm{T} 3$ stretches, is characterized by: i) a larger increase in $n_{v}$ associated with the increase in the ratio $y / h$ until the minimum levels of submersion $(1<y / h<1.25)$ in the sections closest to the dam, where the maximum difference is reached with respect to the most distant ones $(\Delta \mathrm{n}>0.01)$; (ii) a high rate of increase of $n_{v}$ 
up to $y / h=0.75$ in the non-submersion phase in all cases, followed by a lower rate of climb until $y / h=1.25$ in the sections furthest from the dam; (iii) a smoother, progressive descent of $n_{v}$ until $y / h=2.5$, with roughness values becoming lower as the distance to the dam lengthens (e.g. for $y / h=2, n_{v}$ decreases from 0.032 in Up1 (T1) to 0.024 in Up3 (T1), and from 0.035 in Up1 (T3) to 0.027 in Up3 (T3)). On the other hand, downstream, except in section $\mathrm{T} 2$, the scrubs exhibited less roughness than upstream, especially in the section closest to the dam (Dw1), where for $y / h=0.75$ Manning's $n_{v}$ fell approximately $37 \%$ with respect to Up1.
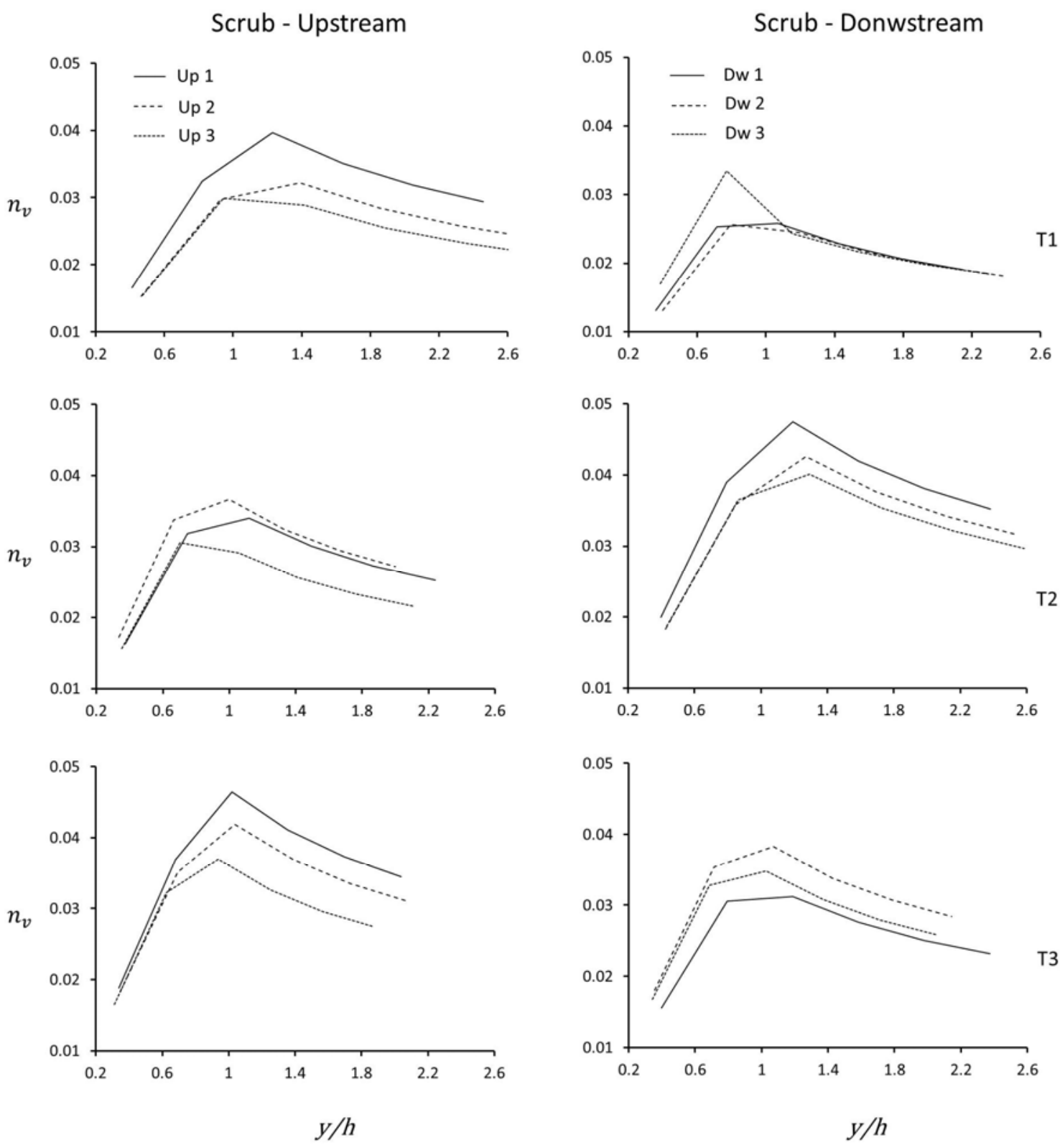

Figure 6. Relationships between Manning's nv and the degree of submergence, $\mathrm{y} / \mathrm{h}$, for scrubs upstream (Up) and downstream (Dw) from check dams T1, T2 and T3. 
The relationships between the scrub $n_{v}$ and the degree of submergence appear to depend here more on the filling state of the check dam and the degree of incision of the downstream bed than on the distance from the dam. Thus, for example, in T3 (a check dam with $75 \%$ filling and an active scour hole) the curves representing these relationships are parallel, indicating a similar rhythm of descent and rise of $n_{v}$ according to the ratio $y / h$. On the other hand, the curves of T1 (completely filled with sediment up to the crest of the dam and with bedload transport in the downstream restoration phase) exhibit a double behavior pattern: first, in low-water conditions, until it exceeds the submersion level, $n_{v}$ rises and falls at a distinct rate according to the section, and then, starting from $y / h=1.25$, it decreases progressively and to the same extent in all sections.

The pattern shown by the herbaceous plants also presents two different modalities according to the sub-reaches (Up or Dw). Generally, upstream of the check dams, the herbaceous plant roughness varied unevenly from one section to another according to the ratio $y / h$. For example, in T2, the coefficient $n_{v}$ versus $\mathrm{y} / \mathrm{h}$ was usually higher in the densely vegetated and near-dam section, Up1, with values of 0.037 for $y / h=1$ and 0.026 for $y / h=2$, and tended to decrease with distance to the dam in less vegetated sections. These results show good agreement with the findings of Järvelä (2002b), for both submerged and unsubmerged conditions and high herbaceous plant density, and with the results obtained by Maghdam and Kouwen (1997), at low vegetation density. Manning's $n_{v}$ decreased with rising flow depth and with increasing velocity in all the Up sections. By contrast, downstream (Dw), the values of $n_{v}$ with respect to the degree of submergence were lower than $\mathrm{Up}$, but there were hardly any differences between sections due to the intense erosive activity that affects the whole sub-reach.

\subsection{Changes in vegetative roughness associated with variation of the hydraulic radius}

New bed forms originated by the construction of dams introduce significant changes in the channel geometry, therefore, in the hydraulic radius, on which depends the degree of roughness of the vegetation (Sandercock et al., 2007). The water depth, and particularly the hydraulic radius, has an unequal effect on the vegetative roughness, depending on the biotechnical characteristics of each species or plant formation, and whether it is totally or partially submerged (Coon 1998; Defra/EA, 2003; Mustaffa et al., 2016). Figure 7 displays the relationship between the hydraulic radius and the vegetation roughness coefficient $\left(n_{v}\right)$ 
estimated for different shrub and scrub formations in the sections upstream of the final check dam (T1). It shows clear behavioral differences in the hydraulic resistance offered by shrubs and scrubs, depending on the variation of the hydraulic radius and the relative distance to the dam. For example, larger shrubs - such as T. canariensis, N. oleander, or R. sphaerocarpa (the latter included in the category of "Other shrubs") - showed elevated hydraulic resistance due to their structure, height, and poor flexibility, with roughness $\left(n_{v}\right)$ values increasing in linear progression with the hydraulic radius from Up3 to Up1 and from Dw1 to Dw3. This is in agreement with the linear relationship between the effective-drag coefficient for verified $n$ values and the hydraulic radius, in densely wooded cross-sections, found by Arcement and Schneider (1989).

By species, the maximum value of $n_{v}$ corresponds to T. canariensis in the Up1 section $\left(n_{v}=\right.$ $0.037,0.07$, and 0.12 for $\mathrm{Rh}=0.5,1.0$, and $1.5 \mathrm{~m}$, respectively) (Figure 7). In the rest of the Up sections, this species also exerts the greatest hydraulic resistance, albeit to a slightly lower degree. These results are consistent with findings from Masjediet al. (2009) and FathiMoghadam et al. (2011), who obtained a higher value of $n$ for taray in comparison to other shrubs and even poplars. The increased channel roughness caused by taray stems contributes highly to increase deposition of sediment along all of this channel reach, in line with the findings of Everitt (1980). Other retama-type shrubs (e.g. R. sphaerocarpa) and N. oleander maintained $n_{v}$ values above 0.05 in flash floods with $\mathrm{Rh}$ exceeding $1 \mathrm{~m}$, adopting the same pattern of decreasing roughness from Up1 to Up3.

The roughness of the scrubs had a very different pattern: the coefficient $n_{v}$ increased with the hydraulic radius up to $\mathrm{Rh}=0.75 \mathrm{~m}$, a threshold from which most of the existing scrubs in Up (T1) were submerged and $n_{v}$ began to decrease. Also, the loss of scrub roughness associated with increasing distance from the dam increased noticeably with the hydraulic radius when the scrub was totally submerged, and to a lesser degree under partial immersion. As a result, Manning's $n_{v}$ values calculated for this type of vegetation do not appear to be normally distributed along all of the restored channel reach; in accordance with Dombroski et al. (2013), species-specific parameters could cause the calculated roughness values to be biased low. 


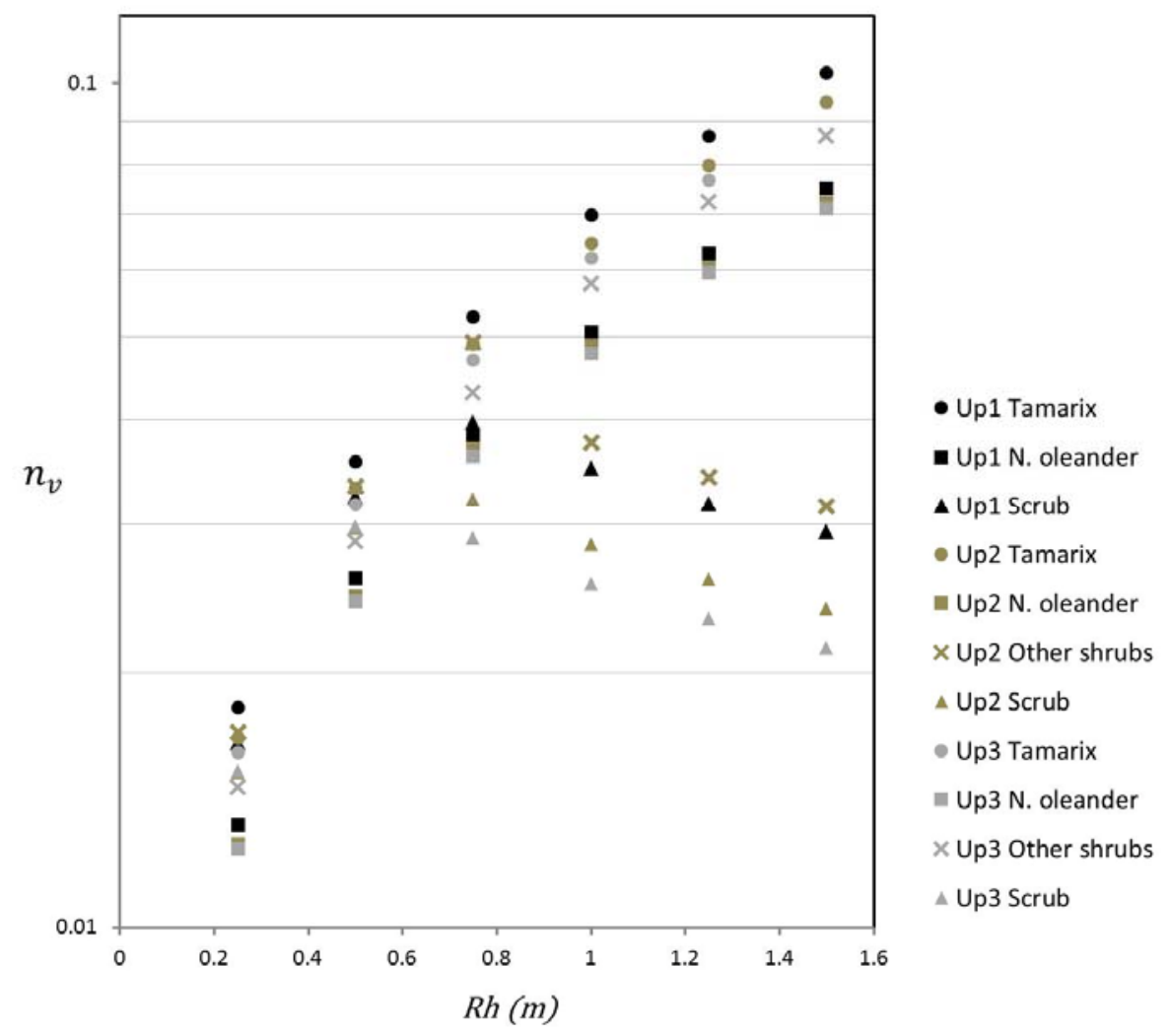

Figure 7. Roughness coefficient nv versus hydraulic radius, calculated for shrub and scrub vegetation upstream and downstream of check dam T1.

The roughness of the herbaceous vegetation also decreased with the hydraulic radius at a higher rate in the sections upstream of the check dams, especially in Up1 (e.g. in Up1-T1, $n_{v}$ is reduced by 0.045 when $R h$ rises from 0.25 to $1.5 \mathrm{~m}$ ). However, the differences in $n_{v}$ between sections within the same sub-reach did not maintain the same pattern in all cases. In flows with a low hydraulic radius $(R h=0.25 \mathrm{~m})$, the range of $n_{v}$ variation along the whole channel sub-reach, upstream and downstream of the dam, was very similar (for T1, $\Delta \mathrm{n}_{\mathrm{v}} \mathrm{Up} 3$ to $\mathrm{Up} 1=0.012 ; \Delta \mathrm{n}_{\mathrm{v}} \mathrm{Dw} 1$ to Dw1 $\left.=0.011\right)$. The trend changed when the hydraulic radius increased and the factor $k$ started to show a smaller relative effect on the vegetative roughness. Thus, differences in herbaceous plant roughness became more pronounced between the sections of the sedimentary wedge than between those monitored downstream, within the new embedded course (for T1 and $R h=1.5 \mathrm{~m}, \Delta \mathrm{n}_{\mathrm{v}} \mathrm{Up} 3$ to Up1 $=0.003 ; \Delta \mathrm{n}_{\mathrm{v}} \mathrm{Dw} 1$ to $\mathrm{Dw} 1=0.007)$.

The differences in vegetation roughness between sections upstream and downstream of the check dams are even more conspicuous if one considers the morphologically active zones along the channel. Field observations revealed that these retention structures changed the 
distribution of vegetated patches and created new areas of local erosion and deposition, thus altering the impact of vegetation on channel roughness (Gurnell et al., 2006; Hession and Curran, 2013).Table 3 and Figure 8 show the vegetative roughness estimated for the entire channel section $\left(n_{v c}\right)$, including scour holes, pools, and riffles, for different hydraulic radii, upstream and downstream of the studied check dams. Upstream, the sediment wedge is crossed by a minor channel which usually ends by forming pipes close to the gabion structure, while downstream a scour hole is developed, followed by final gravel bars. These active bed forms, devoid of vegetation, occupy differing proportions of the surface on the two sides of the dam, thus influencing, in an uneven manner, the overall vegetative roughness $\left(n_{v c}\right)$ of both sub-reaches of the channel.

Table 3. Values of vegetative roughness calculated for the overall channel $\left(\mathrm{n}_{\mathrm{vc}}\right)$, upstream and downstream of check dams T1, T2, and T3, at different hydraulic radii.

\begin{tabular}{cccccccc}
\hline $\begin{array}{c}\text { Channel } \\
\text { reach }\end{array}$ & Rh $(\mathrm{m})$ & Up1 & $\begin{array}{c}\text { Up sections } \\
\text { Up2 }\end{array}$ & Up3 & Dw1 & Dw2 & Dw3 \\
\hline & 0.25 & 0.015 & 0.014 & 0.013 & 0.007 & 0.009 & 0.015 \\
& 0.5 & 0.029 & 0.026 & 0.023 & 0.019 & 0.021 & 0.030 \\
$\mathrm{~T} 1$ & 0.75 & 0.036 & 0.035 & 0.029 & 0.018 & 0.025 & 0.029 \\
& 1 & 0.038 & 0.037 & 0.034 & 0.017 & 0.027 & 0.026 \\
& 1.25 & 0.041 & 0.038 & 0.041 & 0.015 & 0.031 & 0.025 \\
& 1.5 & 0.044 & 0.042 & 0.036 & 0.014 & 0.033 & 0.024 \\
& 0.25 & 0.015 & 0.014 & 0.014 & 0.012 & 0.014 & 0.014 \\
& 0.5 & 0.031 & 0.032 & 0.028 & 0.024 & 0.026 & 0.029 \\
$\mathrm{~T} 2$ & 0.75 & 0.033 & 0.030 & 0.030 & 0.030 & 0.034 & 0.036 \\
& 1 & 0.033 & 0.028 & 0.030 & 0.026 & 0.031 & 0.033 \\
& 1.25 & 0.036 & 0.027 & 0.031 & 0.025 & 0.029 & 0.031 \\
& 1.5 & 0.038 & 0.027 & 0.032 & 0.023 & 0.027 & 0.029 \\
& 0.25 & 0.042 & 0.032 & 0.016 & 0.016 & 0.014 & 0.016 \\
& 0.5 & 0.038 & 0.036 & 0.032 & 0.024 & 0.027 & 0.028 \\
T3 & 0.75 & 0.036 & 0.041 & 0.038 & 0.022 & 0.030 & 0.031 \\
& 1 & 0.034 & 0.038 & 0.035 & 0.020 & 0.027 & 0.026 \\
& 1.25 & 0.030 & 0.034 & 0.029 & 0.017 & 0.023 & 0.023 \\
& 1.5 & 0.028 & 0.032 & 0.027 & 0.014 & 0.019 & 0.020 \\
\hline
\end{tabular}

The greatest contrast of the vegetative roughness of the channel was marked by the differences between the $n_{v c}$ values of the sections closest to the dam (Up1 and Dw1) (Figure 8). This contrast was maximal around the check dams with fillings of 50 to $75 \%$ (e.g. T3), decreased as the dam filled up and bedload transport was restored (e.g. T1), and barely existed during the initial filling phase (e.g. T2). 

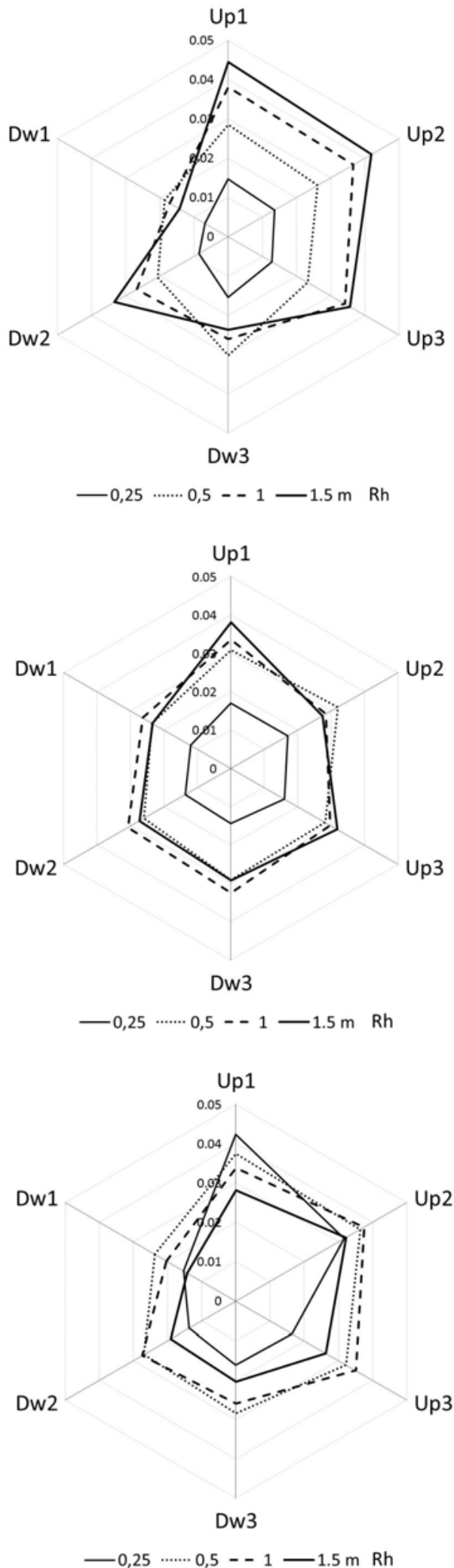

Figure 8. Radial graphs showing the nve values estimated for different channel sections and hydraulic radii. 
The patterns of variation of $n_{v c}$ as a function of $R h$ had, however, a closer relationship with the density of vegetation and the type of plant formation dominant in each channel reach. In general, with similar density values, in sections with predominance of shrubs, the values of $n_{v c}$ tended to increase with the hydraulic radius (Up1, Up2, and Dw2 in T1; Up1 and Up3 in $\mathrm{T} 2$ ). In contrast, in the sections mainly occupied by herbaceous plants, the values of $n_{v c}$ tended to decrease (Up1 in T3) and - where scrubs predominate - $n_{v c}$ rose or decreased depending on whether the plant was partially or totally submerged. This led to a wider range of vegetative roughness accompanying the hydraulic radius than in previous studies on uniform stream reaches (Jarrett, 1985; Righetti and Armanini, 2002; Okamoto and Nezu, 2010).

The relationships between $n_{v}$ and $n_{v c}$ in flash floods of differing hydraulic radius also show the unequal influence of the active bed forms developed on both sides of the dam. In all cases, the best fit of $n_{v c}$ versus $n_{v}$ was obtained with equations of the power type (Figure 9). However, the correlation between the two variables was lower in the Dw sections, especially in high-water conditions, with $R h>0.75 \mathrm{~m}$, where $\mathrm{r}^{2}=0.665$ (Figure 9). This could be explained by a greater heterogeneity of forms of erosion on the bed downstream, associated with different degrees of filling of the check dams. Upstream of the dam the vegetated surface closely resembled the total area of the channel in each section, so that the presence of small incisions or gravel bars barely introduced variations between the values of $n_{v}$ and $n_{v c}\left(\mathrm{r}^{2}=0.94\right.$ for $\left.0.25<R h<1.5 \mathrm{~m}\right)$ (Figure 9). 

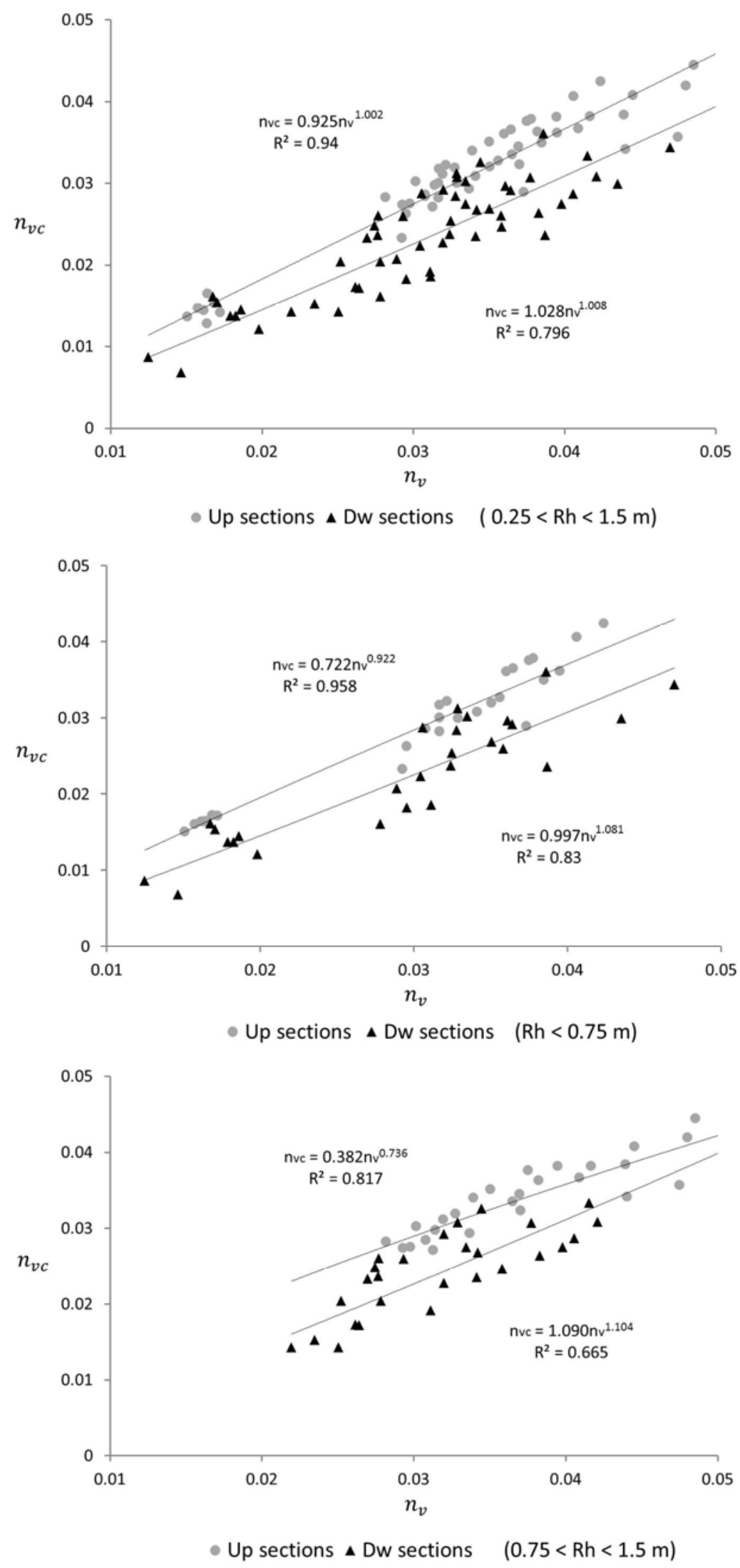

Figure 9. Graphs of nvc versus nv for the analysed Up and Dw sections and different hydraulic radii. 


\subsection{Influence of the vegetative roughness on the flow velocity}

As other authors have already shown for open-channel flows (Temple, 1987; Defra/EA, 2003; Huthoff and Augustijn, 2006; Panigrahia and Khatua, 2015), the distribution of the flow velocity maintains a close relationship with the vegetative roughness coefficient of the channel. In fact, the velocity in the restored reaches studied here was better correlated with the Manning $\left(n_{v}\right)$ friction factor $\left(\mathrm{r}^{2}=0.89\right)$ than with the slope of the bed $\left(\mathrm{r}^{2}=0.82\right)$.

The higher roughness coefficients observed in the upstream sections closest to the check dams imply that the lowest values of velocity would be found in the Up1 sections (Table 4, Figure 10). As the hydraulic radius of the flash flood increases, such differences from the more distant sections become more conspicuous.

Figure 11 shows the effect of the roughness arising from different types of vegetation on the flow velocity for a hydraulic radius of 0.25 to $1.5 \mathrm{~m}$. The variation of the velocity with the hydraulic radius reflects the patterns already described for the roughness of each species in relation to the water level and the ratio $y / h$. Thus, for example, the roughness imposed by $N$. oleander on the final part of the rambla (T1) implies a continuous tendency of the velocity to decrease with the hydraulic radius in both stretches, upstream and downstream of the dam. Upstream, however, the velocity values were lowest in Up1, while downstream the lowest values occurred in the sections furthest from the dam (Dw2 and Dw3). For T. canariensis (Tc) and $N$. oleander (No), the relationships between Manning's $n_{v}$ and the flow velocity were found to be of the power type, with $\mathrm{r}^{2}>0.97$ in all sections upstream of the dam T1 (sections Up-T1-) (Figure 10):

$$
\begin{aligned}
\text { Up1: } & n_{T c}=0.625 v^{-3.21} & n_{N o}=1.249 v^{-3.2} \\
\text { Up2: } & n_{T c}=0.87 v^{-3.21} & n_{N o}=1.495 v^{-3.14} \\
\text { Up3: } & n_{T c}=1.314 v^{-3.19} & n_{N o}=2.215 v^{-3.15}
\end{aligned}
$$


Table 4. Hydraulic variables applied in the calculation of the roughness of the herbaceous vegetation and of Nerium oleander, upstream (Up) and downstream (Dw) of the T2 check dam, for $\mathrm{Rh}=0.5 \mathrm{~m}$.

\begin{tabular}{|c|c|c|c|c|c|c|c|c|c|c|}
\hline \multirow[b]{2}{*}{ Section } & \multirow[b]{2}{*}{$\mathrm{Rh}$} & \multirow[b]{2}{*}{$\mathrm{S}$} & \multirow[b]{2}{*}{$\tau_{0}$} & \multirow[b]{2}{*}{$\mathrm{V}^{*}$} & \multicolumn{3}{|c|}{ Nerium oleander } & \multicolumn{3}{|c|}{ Herbaceous } \\
\hline & & & & & $\mathrm{y} / \mathrm{h}$ & $\mathrm{n}$ & $\mathrm{V}$ & $\mathrm{y} / \mathrm{h}$ & $\mathrm{n}$ & $\mathrm{V}$ \\
\hline \multirow{6}{*}{ Up1 } & 0.25 & 0.028 & 68.6 & 0.26 & 0.11 & 0.019 & 3.56 & 0.56 & -- & -- \\
\hline & 0.50 & 0.028 & 137.3 & 0.37 & 0.23 & 0.037 & 2.88 & 1.11 & 0.036 & 2.90 \\
\hline & 0.75 & 0.028 & 205.9 & 0.45 & 0.34 & 0.054 & 2.54 & 1.67 & 0.027 & 5.09 \\
\hline & 1.00 & 0.028 & 274.6 & 0.52 & 0.45 & 0.072 & 2.33 & 2.22 & 0.025 & 6.68 \\
\hline & 1.25 & 0.028 & 343.2 & 0.59 & 0.57 & 0.089 & 2.17 & 2.78 & 0.024 & 8.16 \\
\hline & 1.50 & 0.028 & 411.9 & 0.64 & 0.68 & 0.107 & 2.06 & 3.33 & 0.020 & 10.8 \\
\hline \multirow{6}{*}{ Up2 } & 0.25 & 0.032 & 78.4 & 0.28 & 0.11 & 0.017 & 4.15 & 0.46 & -- & -- \\
\hline & 0.50 & 0.032 & 156.9 & 0.40 & 0.23 & 0.034 & 3.35 & 0.93 & -- & -- \\
\hline & 0.75 & 0.032 & 235.3 & 0.49 & 0.34 & 0.050 & 2.96 & 1.39 & 0.027 & 5.39 \\
\hline & 1.00 & 0.032 & 313.8 & 0.56 & 0.45 & 0.066 & 2.71 & 1.85 & 0.025 & 7.13 \\
\hline & 1.25 & 0.032 & 392.2 & 0.63 & 0.57 & 0.082 & 2.53 & 2.31 & 0.024 & 8.71 \\
\hline & 1.50 & 0.032 & 470.7 & 0.69 & 0.68 & 0.098 & 2.39 & 2.78 & 0.023 & 10.2 \\
\hline \multirow{6}{*}{ Up3 } & 0.25 & 0.033 & 80.3 & 0.28 & 0.17 & 0.017 & 4.14 & 0.32 & -- & -- \\
\hline & 0.50 & 0.033 & 161.8 & 0.40 & 0.33 & 0.034 & 3.35 & 0.64 & -- & -- \\
\hline & 0.75 & 0.033 & 242.7 & 0.49 & 0.50 & 0.051 & 2.96 & 0.96 & 0.028 & 5.33 \\
\hline & 1.00 & 0.033 & 323.6 & 0.57 & 0.67 & 0.067 & 2.70 & 1.28 & 0.026 & 7.02 \\
\hline & 1.25 & 0.033 & 404.5 & 0.64 & 0.83 & 0.084 & 2.52 & 1.60 & 0.025 & 8.60 \\
\hline & 1.50 & 0.033 & 485.4 & 0.70 & 1.00 & 0.100 & 2.38 & 1.92 & 0.024 & 10.1 \\
\hline \multirow{6}{*}{ Dw1 } & 0.25 & 0.026 & 63.7 & 0.25 & 0.10 & 0.017 & 3.75 & 0.34 & -- & -- \\
\hline & 0.50 & 0.026 & 127.5 & 0.36 & 0.21 & 0.034 & 3.04 & 0.68 & -- & -- \\
\hline & 0.75 & 0.026 & 191.2 & 0.44 & 0.31 & 0.051 & 2.69 & 1.01 & 0.033 & 3.98 \\
\hline & 1.00 & 0.026 & 255.0 & 0.50 & 0.42 & 0.067 & 2.46 & 1.35 & 0.027 & 6.08 \\
\hline & 1.25 & 0.026 & 318.7 & 0.56 & 0.52 & 0.084 & 2.30 & 1.69 & 0.025 & 7.47 \\
\hline & 1.50 & 0.026 & 382.4 & 0.62 & 0.63 & 0.100 & 2.18 & 2.03 & 0.024 & 8.78 \\
\hline \multirow{6}{*}{ Dw2 } & 0.25 & 0.024 & 58.8 & 0.24 & 0.11 & 0.018 & 3.40 & 0.32 & -- & -- \\
\hline & 0.50 & 0.024 & 117.7 & 0.34 & 0.22 & 0.035 & 2.75 & 0.65 & -- & -- \\
\hline & 0.75 & 0.024 & 176.5 & 0.42 & 0.33 & 0.053 & 2.43 & 0.97 & 0.034 & 3.76 \\
\hline & 1.00 & 0.024 & 235.3 & 0.49 & 0.43 & 0.070 & 2.23 & 1.30 & 0.027 & 5.76 \\
\hline & 1.25 & 0.024 & 294.2 & 0.54 & 0.54 & 0.086 & 2.08 & 1.62 & 0.025 & 7.09 \\
\hline & 1.50 & 0.024 & 353.1 & 0.59 & 0.65 & 0.103 & 1.97 & 1.95 & 0.024 & 8.33 \\
\hline \multirow{6}{*}{ Dw3 } & 0.25 & 0.029 & 71.1 & 0.27 & 0.11 & 0.018 & 3.73 & 0.31 & -- & -- \\
\hline & 0.50 & 0.029 & 142.2 & 0.38 & 0.22 & 0.035 & 3.02 & 0.63 & -- & -- \\
\hline & 0.75 & 0.029 & 213.3 & 0.46 & 0.32 & 0.053 & 2.67 & 0.94 & 0.033 & 4.23 \\
\hline & 1.00 & 0.029 & 284.4 & 0.53 & 0.43 & 0.070 & 2.45 & 1.25 & 0.026 & 6.47 \\
\hline & 1.25 & 0.029 & 355.5 & 0.60 & 0.54 & 0.086 & 2.29 & 1.56 & 0.025 & 7.93 \\
\hline & 1.50 & 0.029 & 426.6 & 0.65 & 0.65 & 0.103 & 2.16 & 1.88 & 0.024 & 9.32 \\
\hline
\end{tabular}

$S=$ bed slope $(\mathrm{m} / \mathrm{m}) ; \tau_{0}=$ bed shear stress $\left(\mathrm{N} / \mathrm{m}^{2}\right) ; \mathrm{V}^{*}=$ shear velocity $(\mathrm{m} / \mathrm{s}) ; \mathrm{y} / \mathrm{h}=$ ratio of submergence (water depth / vegetation height); $\mathrm{n}=$ Manning roughness coefficient; $\mathrm{V}=$ flow velocity $(\mathrm{m} / \mathrm{s})$. 


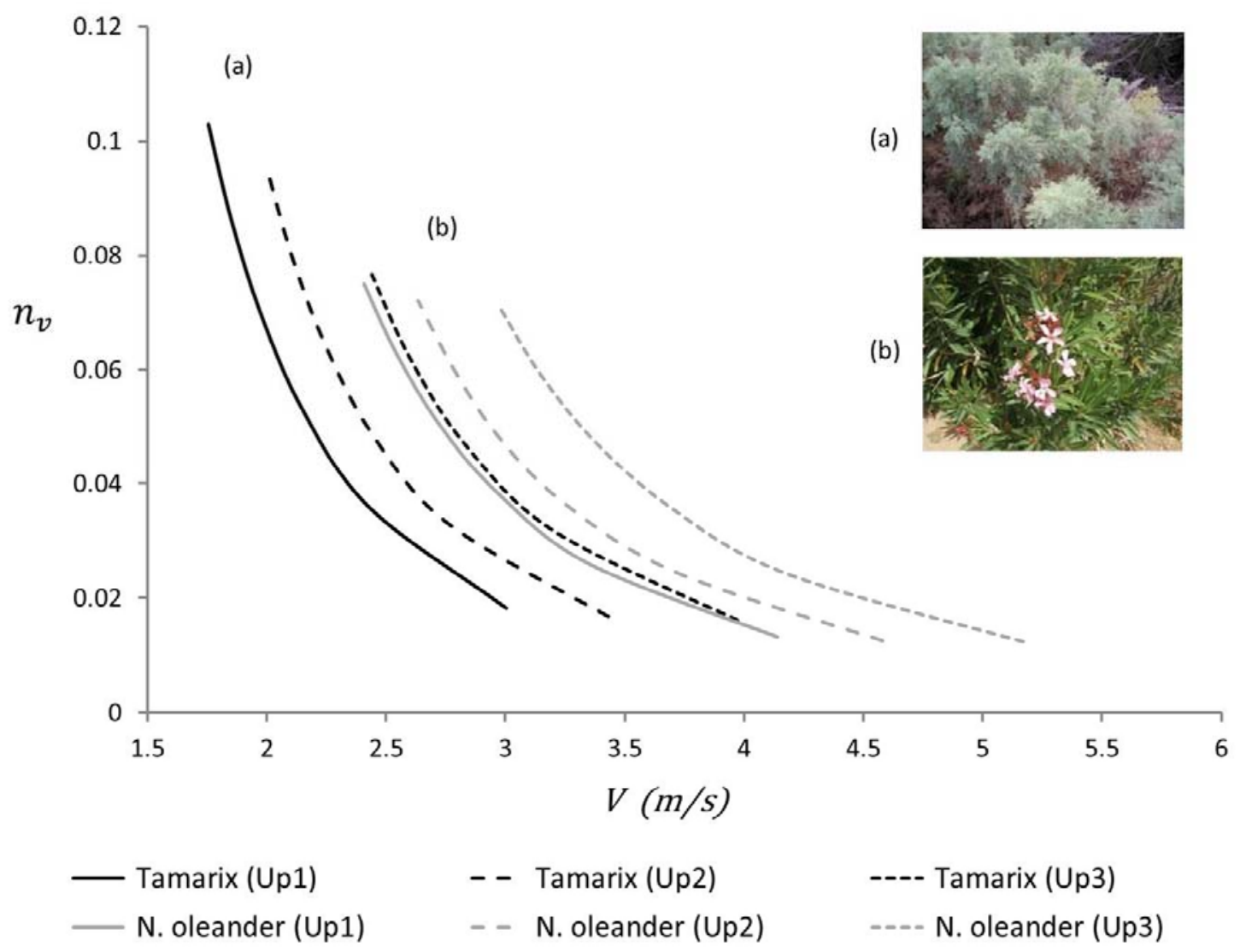

Figure 10. Roughness coefficient nv versus flow velocity for Tamarix canariensis and Nerium oleander upstream from the check dam T1.

These equations reveal a decrease in the $n_{v}$-value as flow velocity increases, a result of streamlining of vegetation and flattening of roughness elements, as pointed out before by Järvelä (2004), Ebrahimi et al. (2008), and Fathi-Moghadam and Drikvandi (2012).

The effect of the scrub on the channel roughness is clearly noticeable in the change in velocity with the hydraulic radius, which follows the behavior patterns already defined upstream and downstream of the check dam. The initial tendency of the roughness to increase was maintained until the scrub submersion level, where $n_{v}=0.037$ for Up1, and corresponds to a decrease in water velocity - which reached $2.4 \mathrm{~m} / \mathrm{s}$ at that level and section. After this threshold, with $R h=0.8 \mathrm{~m}$, the velocity increased with the hydraulic radius to 5.1 $\mathrm{m} / \mathrm{s}$ in the section Up1 (Figure 11). 

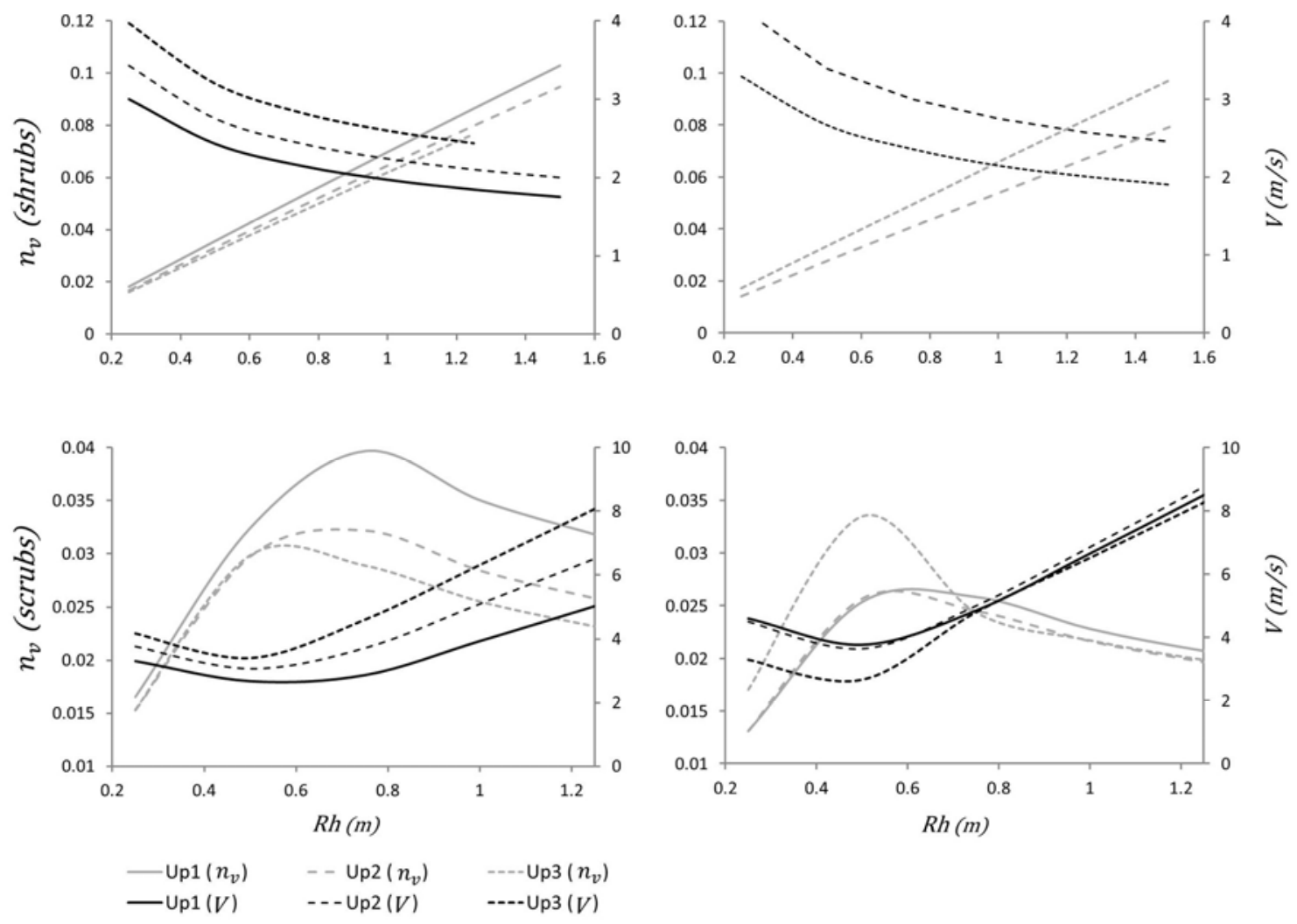

Figure 11. Flow velocity, V, versus vegetative roughness, nv, for shrubs and scrub at different hydraulic radii, in channel sections upstream (left) and downstream (right) of the check dam T1.

The same behavior was observed in the upstream sections more distant from the dam (Up2 and Up3), but with progressively lower velocities in the initial phase of partial submergence of the scrub and greater velocities once it was totally submerged (Figure 11). Downstream of the dam, the variation in velocity in relation to the hydraulic radius was similar to that upstream, but the values and rate of variation were quite different from one section to another. From total submersion onwards, the variation between the Dw sections grew according to the hydraulic radius, with the difference from Dw1 to Dw2 being greater as the $R h$ augmented.

The regression analysis, applied to relationships of flow velocity (V) versus $R h$ in the sections closest to check dam T1, gave a good fit for polynomial equations in the form of: 


$$
\begin{array}{lll}
V=0.858 R h^{2}-2.436 R h+3.512 & \mathrm{r}^{2}=0.988 & \text { (shrubs in section Up1) } \\
V=1.183 R h^{2}-3.357 R h+4.871 & \mathrm{r}^{2}=0.989 & \text { (shrubs in section Dw2) } \\
V=4.933 R h^{2}-5.521 R h+4.311 & \mathrm{r}^{2}=0.979 & \text { (scrubs in section Up1) } \\
V=6.939 R h^{2}-6.136 R h+5.502 & \mathrm{r}^{2}=0.975 & \text { (scrubs in section Dw1) }
\end{array}
$$

In the case of herbaceous plants, the velocity increased continuously as the hydraulic radius increased, due to the lower friction that they produce in accordance with their height and submerged area projected into the stream (Kutija and Hong, 1996). As opposed to the tall shrubs, a very low initial velocity was abruptly replaced by high values, especially downstream $(\mathrm{Dw})$, due to the decrease in roughness imposed by the submersion of the herbaceous stems. A wide range of deflected height in this type of flexible plant was found to be highly dependent on the flow velocity and depth by Stephan and Gutknecht (2002), and Järvelä (2004).

The influence of the dams was even more notable in the variations of the flow velocity associated with the changes in the overall vegetative roughness of the channel $\left(n_{v c}\right)$ in relation to the hydraulic radius. Figure 12 shows such variations in the sections monitored upstream of the check dams T1, T2, and T3. From this it can be inferred that the relationships of $n_{v c}$ and $\mathrm{V}$ with $R h$ differ among the sections of the same stretch, such differences increasing with the morphological alteration imposed by each grade control structure.

The behavior of the three sections considered in the morphologically least disturbed stretch (T2) was very similar, with a clear inflection point in the velocity curve around $R h=0.5 \mathrm{~m}$ (Figure 12). By contrast, in T3, affected by a check dam filled to $75 \%$ of its capacity, the curves of the $n_{v c}$ and velocity of the section nearest to the dam contrasted with those of the more distant sections. There was greater variation among the sections of the stretch $\mathrm{T} 1$, affected by a completely silted dam: the inflection point of the velocity curve occurred at $R h$ $=0.7 \mathrm{~m}$ in $\mathrm{Up} 1$ and $\mathrm{Up} 2$ and at $R h=1.25 \mathrm{~m}$ in Up3, the forms of the curve being very different. 

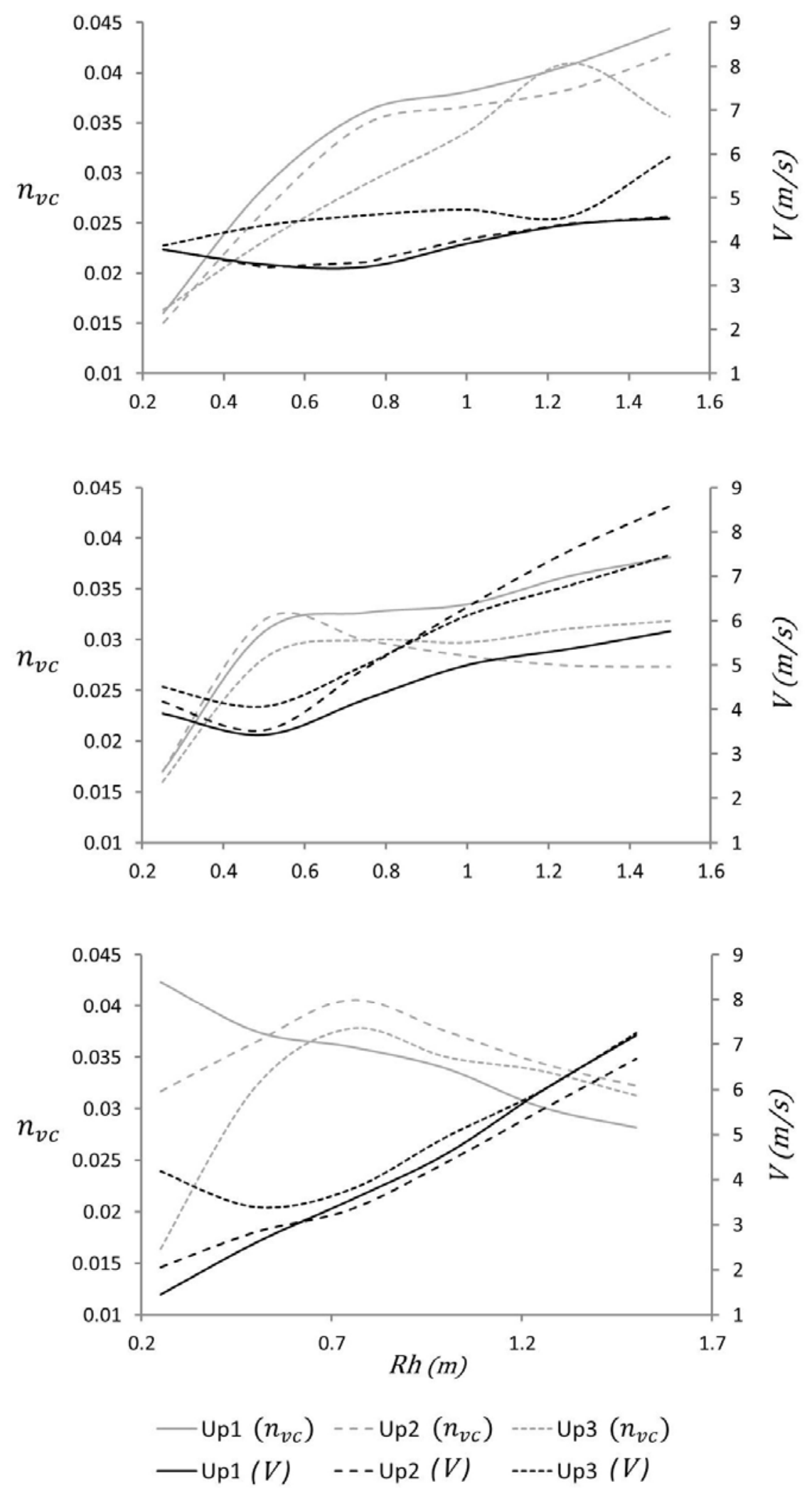

Figure 12. Flow velocity, V, versus vegetative roughness along the overall channel bed, $\mathrm{n}_{\mathrm{vc}}$, in sections upstream from check dams T1 (upper graph), T2 (middle graph) and T3 (lower graph). 


\section{CONCLUSIONS}

It is evident that the check dams installed for the control of erosion in torrential streams such as those analysed here, besides modifying the morphology of the affected channels, also have very significant effects on the spatial distribution of vegetation along the new bedforms created.

The geomorphological changes that they introduce imply important adjustments in the sedimentary dynamics (upstream) and the erosion processes (downstream), which alter the conditions of colonization and plant growth for each corrected channel reach.

Upstream, vegetation roughness increased with proximity to the check dam and downstream the tendency was reversed - the most distant sections recovered part of their natural dynamics, the vegetation contributing a higher coefficient of roughness. Concerning the hydraulic radius and the degree of submergence during the flash floods, the variation of the vegetative roughness was diversified and included different trend modalities and more complex patterns, depending on the state of submersion (total or partial) of the plants, associated with the level of sedimentary filling of the check dams.

Hence, it can be verified that, although each type of plant behaved differently in relation to its resistance to the flow, its relative effect on the overall vegetative roughness of each channel reach always followed the same differentiated behaviour according to the sections. Thus, the density and roughness values of the channel decreased progressively upstream, from the section adjacent to each dam to the tail of its sediment wedge, while downstream this tendency was reversed, the minimum values occurring in the sections located at the foot of the structures and the maximums at the end of the scour holes.

Consequently, upstream of the check dams, it was the section closest to them (Up1) that normally registered the lowest velocity values, while downstream it was the distal section (Dw3), where the bed becomes more stable and vegetation colonizes more easily. In this type of corrected channel - in which the morphological adjustments produced by the installation of check dams have significantly diminished the bed slope, thus reducing the differences between the slopes of the analysed channel reaches - it is beyond doubt that the vegetative roughness has played an essential role in the variation of the flow velocity. The consideration of such plant roughness patterns and their effects on hydraulic resistance in torrential channels affected by check dams is thus a very useful instrument for the prevention and management of flash floods in semi-arid Mediterranean basins that are the object of hydrological correction projects and works. However, the effects of these grade control structures on the dynamics of torrential Mediterranean streams are multiple and complex, 
and their study requires consideration of other components of roughness, in particular the bed particle size. The combined action of both types of roughness (vegetative and based on surface-sediment texture) and its variation, mainly associated with morphological changes imposed by check dams, are aspects that deserve to be analysed in more depth in future investigations.

\section{Acknowledgments}

We wish to thank the reviewers, particularly Professor Yeboah Gyasi-Agyei, for his thorough revision which has allowed us to improve the original version of the paper.

\section{Funding}

This paper was carried out within the research project PI/13 framework, "Hydrological and geomorphological response to the fluvial torrential systems affected by forestryhydrological restoration works in semiarid catchments in South East of Spain", financed by the Fundación Instituto Euromediterráneo de Hidrotecnia, European Council, and Comunidad Autónoma de la Región de Murcia, Spain.

\section{REFERENCES}

Aberle, J., and Järvelä, J., 2013. Flow resistance of emergent rigid and flexible vegetation floodplain vegetation. Journal of Hydraulic Research, 51(1), 33-45. doi: 10.1080/00221686. 2012.754795

Abood, M.M., Yusuf, B., Mohammed, T.A., and Ghazali, A.H., 2006. Manning roughness coefficient for grass-lined channel. Journal of Science and Technology, 13(4), 317-330.

Alcaraz, F., Álvarez, J., Delgado, M.J., Faz, A., and Inocencio, C., 1999. La vegetación. In: Atlas del Medio Natural de la región de Murcia, Instituto Tecnológico Geominero, Consejería de Política Territorial y Obras Públicas: Murcia, 15-35.

Arcement, G.J., and Schneider, V.R., 1989. Guide for Selecting Manning's Roughness Coefficients for Natural Channels and Flood Plains. U. S. Geological Survey, Water-Supply, Paper 2339, Denver, $38 \mathrm{p}$.

Armanini, A., Righetti, M., and Grisenti, P., 2005. Direct measurement of vegetation resistance in prototype scale. Journal of Hydraulic Research, 43(5), 481-487. doi: 10.1080/00221686.2009. 9522010

Boix-Fayos, C., Barbera, G.G., López-Bermúdez, F., and Castillo, V.M., 2007. Effects of checkdams, reforestation and land-use changes on river channel morphology: Case study of the Rogativa catchment (Murcia, Spain). Geomorphology, 91, 103-123. doi: 10.1016/j.geomorph. 2007.02.003

Boix-Fayos, C., Vente, J., Martínez-Mena, M., Barbera, G.G., and Castillo, V., 2008. The impact of land use change and check-dams on catchment sediment yield. Hydrological Processes, 22, 4922 4935. doi: 10.1002/hyp.7115 
Bombino, G., Tamburino, V., Zema, D.A., and Zimbone, S.M., 2010. The influence of check dams on fluvial processes and riparian vegetation in mountain reaches of torrents. Journal of Agricultural Engineering, 3: 37-47. doi: 10.4081/jae.2010.3.37

Bombino, G., Boix-Fayos, C., Gurnell, A.M., Tamburino, V., Zema, D.A., and Zimbone, S.M., 2014. Check dam influence on vegetation species diversity in mountain torrents of the Mediterranean environment. Ecohydrology, 7, 678-691. doi: 10.1002/eco.1389

Castillo, V., Mosch, W., Conesa-García, C., Barberá, G., Navarro-Cano, J.A., and López-Bermúdez, F., 2007. Effectiveness and geomorphological impacts of check dams for soil erosion control in a semiarid Mediterranean catchment: El Cárcavo (Murcia, Spain). Catena, 70, 416-427. doi: 10.1016/j.catena.2006.11.009

Castillo, C., Pérez, R., and Gómez, J.A., 2014. A conceptual model of check dam hydraulics for gully control: efficiency, optimal spacing and relation with step-pools. Hydrology and Earth System Sciences, 18, 1705-1721. doi: 10.5194/hess-18-1705-2014

Conesa-García, C., García-Lorenzo, R., and López-Bermúdez, F., 2007. Bed stability variations after check dam construction in torrential channels (South-East Spain). Earth, Processes and Land Forms, 32, 2165-2184. doi: 10.1002/esp.1521

Conesa-García, C. and Pérez Cutillas, P. (2007): Relation between the location of check dams and adjacent vegetation cover in ephemeral gullies (southeast Spain). In: J. Casalí and R. Giménez, eds. Progress in Gully Erosion Research. Universidad Pública de Navarra: Pamplona, 30-32.

Conesa-García, C., and García-Lorenzo, R., 2009a. The effectiveness of check dams on the control of general transitory bed scouring in semiarid catchment areas (South East Spain). Water and Environment Journal, 23(1), 1-14. doi: 10.1111/j.1747-6593.2007.00099.x

Conesa-García, C., and García-Lorenzo, R., 2009b. Local scour estimation at check dams in torrential streams in South East Spain. Geografiska Annaler: Series A, Physical Geography, 91, 159-177. doi: 10.1111/j.1468-0459.2009.00361.x

Conesa-García, C., and García-Lorenzo, R., 2009c. Bankfull hydraulic geometry adjustments caused by check dams in ephemeral channels (South-East Spain, Western Mediterranean). In: W.P. Hayes and M.C. Barnes, eds. Dams: Impacts, Stability and Design. Nova Science Publishers, Inc.: New York, 75-99.

Conesa-García, C., and Lenzi, M.A. (eds.) 2010. Check Dams, Morphological Adjustments and Erosion Control in Torrential Streams. Collection: Environmental Science, Engineering and Technology. Nova Science Publishers, New York, 339 p.

Coon, W.F., 1998. Estimation of roughness coefficients for natural stream channels with vegetated banks. U.S. Geological Survey, Water-Supply, Paper 2441, 133 p.

Darby, S.E., 1999. Effect of Riparian Vegetation on Flow Resistance and Flood Potential, Journal of Hydraulic Engineering, 125(5), 443 - 454. doi: 10.1061/(ASCE)0733-9429

Defina, A., and Bixio, A.C., 2005. Mean flow and turbulence in vegetated open channel flow, Water Resources Research, 41 (7), 1-12, W07006. doi: 10.1029/2004WR003475

DEFRA/Environment Agency (2003): Reducing Uncertainty in River Flood Conveyance, Roughness Review. Prepared by K. Fisher and H. Dawson, Project W5A-057, 204 p.

Devi, T.B., Sharma, A., and Kumar, B., 2017. Studies on emergent flow over vegetative channel bed with downward seepage, Hydrological Sciences Journal, 62 (3), 408-420. doi: 10.1080/ 02626667.2016.1230673

Dombroski, D., Greimann, B., Lai, Y., Huang, V., Fotherby, L., Stone, M.C., and L. Chen. 2013. Modeling Interactions of Flow and Vegetation for Improved Riverine System Management. American Water Resources Association Specialty Conference on Environmental Flows, June 2425, Hartford, Connecticut.

Ebrahimi, N.G., Fathi-Moghadam, M., Kashefipour, S.M., Saneie, M., and Ebrahimi, K., 2008. Effects of Flow and Vegetation States on River Roughness Coefficients. Journal of Applied Sciences, 8, 2118-2123. doi: 10.3923/jas.2008.2118.2123

Everitt. B.L., 1980. Ecology of saltcedar - a plea for research. Environmental Geology, 3, 77-84. doi:10.1007/BF02473474

Fathi-Moghadam, M., Drikvandi, K., Lashkarara, B., and Hammadi, K., 2011. Determination of friction factor for rivers with nonsubmerged vegetation in banks and floodplains. Scientific Research and Essays, 6(22): 4714-4719. doi: 10.5897/SRE11.751 
Fathi-Moghadam, M., and Drikvandi, K., 2012. Manning Roughness Coefficient for Rivers and Flood Plains with Non-Submerged Vegetation. International Journal of Hydraulic Engineering, 1(1): 1-4. doi: 10.5923/j.ijhe.20120101.01

Fisher-Antze, T., Stoesser, T., Bates, P., and Olsen, N.R.B., 2001. 3D numerical modelling of openchannel flow with submerged vegetation, Journal of Hydraulic Research, 39(3), 303-310. doi: $10.1080 / 00221680109499833$

Freeman, G.E., Rahmeyer, W.H., and Copeland, R.R., 2000. Determination of resistance due to shrubs and woody vegetation. Technical Report, ERDC/CHL TR-00-25, U.S. Army Engineer Research and Development Center, Vicksburg, MS.

Galia, T., and Skarpich, V., 2016. Response of Bed Sediments on the Grade-Control Structure Management of a Small Piedmont Stream. River Research and Applications, version of record online: 21 November 2016. doi: 10.1002/rra.3111

Gurnell, A.M., van Oosterhout, M.P., de Vlieger, B., and Goodson, J.M., 2006. Reach-scale interactions between aquatic plants and physical habitat: River Frome, Dorset. River Research and Applications, 22(6), 1535-1467. doi: 10.1002/rra.929

Hession, W.C., and Curran, J.C., 2013. The Impacts of Vegetation on Roughness in Fluvial Systems. In: J.F. Shroder, D.R. Butler and C.R. Hupp, eds. Treatise on Geomorphology, Vol 12, Ecogeomorphology, Academic Press: San Diego, 75-93.

Huthoff, F., and Augustijn, D.C.M., 2006. Hydraulic resistance of vegetation: predictions of average flow velocities based on a rigid-cylinders analogy, University of Twente, CE\&M research report 2006R-001/WEM-003, Enschede, The Netherlands, 67 p.

Järvelä, J., 2002. Flow resistance of flexible and stiff vegetation: a flume study with natural plants. Journal of Hydrology, 269(1-2), 44-54. doi: 10.1016/S0022-1694(02)00193-2

Järvelä, J., 2004. Determination of flow resistance caused by non-submerged woody vegetation. International Journal of River Basin Management, 2(1), 61-70. doi: 10.1080/15715124.2004. 9635222

Järvelä, J., 2005. Effect of Submerged Flexible Vegetation on Flow Structure and Resistance. Journal of Hydrology, 307(1-4), 233-241. doi: 10.1016/j.jhydrol.2004.10.013

Klopstra, D., Barneveld, H.J., van Noortwijk, J.M., and van Velzen, E.H., 1997. Analytical model for hydraulic roughness of submerged vegetation. In: Managing Water: Coping With Scarcity and Abundance, Proceedings IAHR, American Society of Civil Engineering, New York, 775 - 780.

Kouwen, N., 1988. Field Estimation of the Biomechanical Properties of Grass. Journal of Hydraulics Research, 26(5), 559 - 568. doi: 10.1080/00221688809499193

Kouwen, N., and Fathi-Moghadam, M., 2000. Friction factors for coniferous trees along rivers. Journal of Hydraulic Engineering, 126(10), 732-740.

Kouwen N., and Li, R.M., 1980. Biomechanics of Vegetative Channel Linings. Journal of the Hydraulic Division, ASCE, 106(6), 1085-1103.

Kouwen, N., and Unny, T.E., (1973). Flexible Roughness in Open Channels. Journal of the Hydraulics Division, ASCE, 99(5): 713-728.

Kubrak, E., Kubrak, J., and Rowinski, P.M., 2008. Vertical velocity distributions through and above submerged, flexible vegetation. Hydrological Sciences Journal, 53(4), 905-920. doi: 10.1623/hysj.53.4.905

Kutija, V., and Hong, H.T.M., 1996. A numerical model for assessing the additional resistance to flow introduced by flexible vegetation. Journal of Hydraulic Research, 34 (1), 99-114. doi: 10.1080/00221689609498766

Jarrett, R.D., 1985. Determination of roughness coefficients for streams in Colorado. WaterResources Investigations Report 85-4004, U.S. Geological Survey, Lakewood, Colorado, 54 p.

López, F., and García, M.H., 2001. Mean flow and turbulence structure of open-channel flow through non-emergent vegetation, Journal of Hydrological Engineering, 127(5), 392-402. doi: 10.1061/(ASCE)0733-9429(2001)127:5(392)

Masjedi, A., Fathi Moghadam, M., Shomalnasab, B., 2009. Investigation of Nonsubmerged Vegetation Cover Resistance Against Flow in Riversides. JWSS - Journal of Water and Soil Science, 12 (46), 533-541. 
Mustaffa, N., Ahmad, N.A, and Razi, M.A.M., 2016. Variations of Roughness Coefficients with Flow Depth of Grassed Swale. IOP Conference Series: Materials Science and Engineering, 136. doi: 10.1088/1757-899X/136/1/012082

Naot, D., Nezu, I., and Nakagawa, H., 1996. Unstable patterns in partly vegetated channels. Journal of Hydraulic Engineering, 122(11), 671-673. doi. 10.1061/(ASCE)0733-9429(1996)122:11(671)

Negm, A.M., 2008. Effect of partially or fully submerged vegetation on roughness coefficients in rectangular open channels. Proceedings of ICFDP9: Ninth International Congress of Fluid Dynamics \& Propulsion, December 18-21, 2008, Alexandria, Egypt.

Nepf, H.M., 1999. Drag, turbulence, and diffusion in flow through emergent vegetation. Water Resources Research, 35(2), 479-489. doi: 10.1029/1998WR900069

Nepf, H.M., and Vivoni, E.R., 2000. Flow structure in depth-limited, vegetated flow. Journal of Geophysical Research, 105, 28,547 - 28,557. doi: 10.1029/2000JC900145

Nichols, M.H., Polyakov, V.O., Nearing, M.A., and Hernández, M., 2016. Semiarid Watershed Response to Low-Tech Porous Rock Check Dams. Soil Science, 181(7), 275-282. doi: 10.1097/ SS.0000000000000160.

Norman, L.M., Brinkerhoff, F., Gwilliam, E., Guertin, D.P., Callegary, J., Goodrich, D.C., Nagler. P.L., and Gray, F., 2016. Hydrologic response of streams restored with check dams in the Chiricahua Mountains, Arizona. River Research and Applications, 32, 519-527. doi: 10.1002/ rra. 2895

Nyssen, J., Veyret-Picot, M., Poesen, J., Moeyersons, J., Haile, M., Deckers, J., and Govers, G., 2004. The effectiveness of loose rock check dams for gully control in Tigray, northern Ethiopia. Soil Use and Management, 20(1), 55-64. doi: 10.1111/j.1475-2743.2004.tb00337.x

Okamoto, T., and Nezu, I., 2010. Flow resistance law in open-channel flows with rigid and flexible vegetation. In: A. Dittrich, et al., eds, River Flow, Karlsruhe, Germany. pp. 261-268.

Panigrahia, K., and Khatua, K.K., 2015. Prediction of Velocity Distribution in Straight Channel with Rigid Vegetation. Aquatic Procedia, 4, 819-825. doi: 10.1016/j.aqpro.2015.02.102

Pasche, E., and Rouvé, G., 1985. Overbank flow with vegetatively roughened flood plains. Journal of Hydraulic Engineering, 111(9), 1262-1278.

Petryk, S., and Bosmajian, G.B., 1975. Analysis of flow through vegetation. Journal of the Hydraulic Division, ASCE, 101(7), 871-884.

Polyakov, V.O., Nichols, M.H., McClaran, M.P., and Nearing, M.A., 2014. Effect of check dams on runoff, sediment yield, and retention on small semiarid watersheds. Journal of Soil and Water Conservation, 69(5), 414-421. doi:10.2489/jswc.69.5.414

Puigdefábregas, J., and García-Ruiz, J.M., 1985. Efectos de la construcción de pequeñas presas en causes anastomosados del Pirineo Central. Cuadernos de Investigación Geográfica, 11, 91-102. doi: 10.18172/cig.946

Rahmeyer, W., Werth, D., and Cleere, R., 1995. The study of resistance and stability of vegetation in flood channels. Utah State University, Lab Rep. USU-376, Vicksburg, Miss.

Righetti, M., 2008. Analysis of the flow in channels with flexible vegetation using double-averaging method. Acta Geophysica, 56, 801-823. doi: 10.2478/s11600-008-0032-z

Righetti, M., and Armanini, A., 2002. Flow resistance in open channel with sparsely distributed bushes. Journal of Hydrology, 269, 55- 64. doi: 10.1016/S0022-1694(02)00194-4

Sandercock, P.J., Hooke, J.M., and Mant, J.M., 2007. Vegetation in dryland river channels and its interaction with fluvial processes. Progress in Physical Geography, 31(2), 107-129. doi: $10.1177 / 0309133307076106$

Shi, J.Z., Li, Y.-H., Hughes, J.M.R., and Zhao, M., 2013. Hydrological characteristics of vegetated river flows: a laboratory flume study. Hydrological Sciences Journal, 58(5), 1047-1058. doi: $10.1080 / 02626667.2013 .797580$

Shimizu, Y., and Tsujimoto, T., 1994. Numerical analysis of turbulent open-channel flow over a vegetation layer using a turbulence model. Journal of Hydroscience and Hydraulic Engineering, $11,57-67$.

Souliotis D., and Prinos P., 2010. 3-D Numerical computations of turbulence in a partially vegetated shallow channel. In: A. Dittrich, et al., eds. Proceedings of the International Conference on Fluvial Hydraulics, September 08-10, 2010, Braunschweig, Germany, pp. 83-90. 
Stephan, U., and Gutknecht, D., 2002. Hydraulic resistance of submerged flexible vegetation. Journal of Hydrology, 269(1-2), 27-43. doi:10.1016/S0022-1694(02)00192-0

Temple, D. M., 1987. Closure of 'Velocity Distribution Coefficients for Grass-Lined Channels'. Journal of Hydraulic Engineering, ASCE, 113(9), 1224-1226.

Wu, F.Ch., Shen, H.W., and Chou, Y.J., 1999. Variation of Roughness Coefficients for unsubmerged and submerged vegetation. Journal of Hydraulic Engineering, 125(9), 934-942. doi: 10.1061/(ASCE)0733-9429(1999)125:9(934)

Wu, W., He, Z., and Wang, S.S.Y., 2006. Flow conveyance and sediment transport capacity in vegetated channels. The 7th International Conference on Hydroscience and Engineering (ICHE2006), Sep 10 -Sep 13, Philadelphia, USA.

Wynn-Thompson, T., and Hall, K., 2012. Predicting friction factor in herbaceous emergent wetlands, American Geophysical Union, Fall Meeting. December 2012. 